\title{
DE DE GRUYTER OPEN \\ "From Adam to Moses": the Typology of the Old Testament Characters from the Kontakia of Romanos the Melodist and its Assessment on the Great Canon of Andrew of Crete
}

\author{
Alexandru Prelipcean ${ }^{*}$
}

\begin{abstract}
The subject of the typological images within the kontakia of Romanos the Melodist, the Byzantine Hymnographer who, through his quill pen, fascinated the entire Byzantine Empire in the sixth century, was developed in several topic-related studies. What in fact is the aim of the present study? It tries, on the one hand, to identify those parts within the kontakia of Romanos that speak directly about the typology of the Old Testament characters (including the chronological period from Adam to Moses), and secondly, to examine how Andrew of Crete, (re) known in the Christian hymnography as the "inventor" of the canon, reflects these typological images approximately two centuries after the death of Romanos. In other words, we are concerned with how the typology is present in the new hymnographic production of the eighth century, known under the title of canon, and how the transition from the typology existing in the kontakion to the one in the canon was achieved.
\end{abstract}

Keywords: Saint Romanos the Melodist, Saint Andrew of Crete, kontakia, Great Canon, typology, hymnography, Old Testament

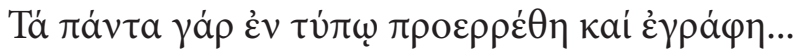
$\sum \grave{\varepsilon} I \eta \sigma o u ̃ ~ \delta \eta \lambda o \tilde{\sigma o v ~ a i ~} \gamma \rho a \varphi a i ́$

[For all the accounts in the Bible predict through prototypes... The Scriptures point you out, Jesus]

The subject of the typological images within the kontakia of Romanos the Melodist ${ }^{1}$, the Byzantine Hymnographer who, through his quill pen, fascinated the entire Byzantine Empire in the sixth century, was developed

\footnotetext{
*Alexandru Prelipcean, Ph.D. candidate at the "Aristotle" University of Thessaloniki and Associate assistant at the Faculty of "Dumitru Stăniloae" Orthodox Theology from Iași. Contact details: Str. Cloşca, no. 9, 700066, Iasi, Romania; e-mail: alprelipcean@yahoo.com

${ }^{1}$ For all the kontakia of Romanos the Melodist we used the two well known critical editions, namely: Paul Maas, Konstantin Athanasios Trypanis (ed.), Sancti Romani Melodi Cantica. Cantica genuina, Oxford 1963; José Grosdidier de Matons (ed.), Romanos le Mélode. Hymnes, in: Sources Chrétiennes, vol. I, no. 99, Paris 1964; vol. II, no. 110, 1965; vol. III, no. 114, 1965; vol. IV, no. 128, 1967, vol. V, no. 283. For the English translation we used the edition: Marjorie Carpenter, Kontakia of Romanos, Byzantine Melodist, vol. I: On the person of Christ, vol. II: On Christian life, Columbia 1970-1973.
} 
in several topic-related studies. Clearly, the scientific literature was enriched in recent decades with numerous contributions that directly or indirectly touched the topic of the kontakia of Romanos the Melodist. We have to mention the Ph.D. theses written by R.J. Reichmuth ${ }^{2}$, J. Grosdidier de Matons ${ }^{3}$, R.J. Schork ${ }^{4}$, Ioannis G. Kourembeles ${ }^{5}$, Alexander S. Korakidis ${ }^{6}$, Christelle Mulard $^{7}$, Sarah Elizabeth Gador-Whyte ${ }^{8}$ and Uffe Holmsgaard Eriksen? ${ }^{9}$. The first four authors cited in this list have actually contributed the most to the recovery of the typological images of Romanos's kontakia.

What in fact is the aim of the present study? It tries, on the one hand, to identify those parts within the kontakia of Romanos that speak directly about the typology of the Old Testament characters (including the chronological period from Adam to Moses), and secondly, to examine how Andrew of Crete, (re)known in the Christian hymnography as the "inventor" of the canon $^{10}$, reflects these typological images approximately two centuries after

${ }^{2}$ Roland Joseph Reichmuth, Typology of the Genuine Kontakia of Romanos the Melodist, Phd degree, University of Minnesota 1975 (in manuscript).

3 J. Grosididier de Matons, Romanos le Mélode et les origines de l'hymnographie byzantine, These presentée devant l'Université de Paris IV 1974, p. 568-573 (in manuscript); idem, Romanos le Mélode et la origines de la poésie religieuse a Byzance, foreword by Paul Lemerle, Paris 1977 , p. 258-260.

4 R. Joe Schork, "Typology in the kontakia of Romanos" in: Studia Patristica, 6 (1962), p. 211-220; idem, Sacred Song from the Byzantine Pulpit: Romanos the Melodist, Gainesville 1995, p. 14-16.

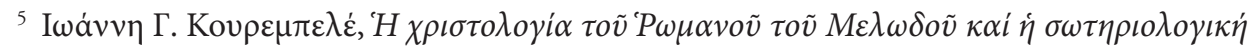

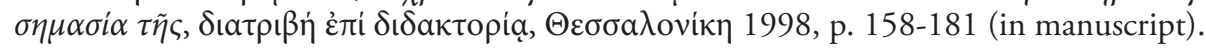

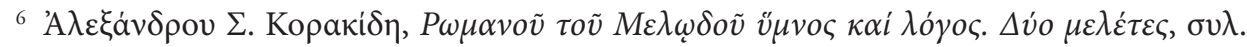

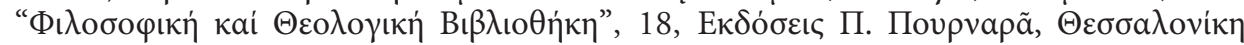

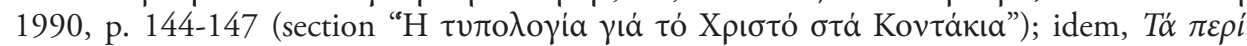

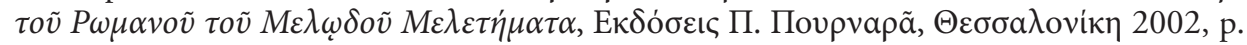

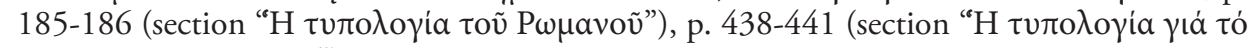

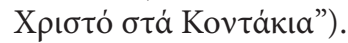

${ }^{7}$ Christelle Mulard, La pensée symbolique de Romanos le Mélode, $\mathrm{PhD}$ thesis, Strasbourg 2011, p. 107-122 (in manuscript).

${ }^{8}$ Sarah Elizabeth Gador-Whyte, Rhetoric and Ideas in the Kontakia of Romanos the Melodist, Submitted in total fulfilment of the requirements of the degree of Doctor of Philosophy, Center for Classics and Archaeology, The University of Melbourne 2011, p. 89-101 (in manuscript).

${ }^{9}$ Uffe Holmsgaard Eriksen, Drama in the Kontakia of Romanos the Melodist: A Narratological Analysis of Four Kontakia, PhD dissertation, Graduate School of Arts, Aarhus University, 2013, p. 120-121, 227-228 (in manuscript).

10 Although there are voices who deny Andrew of Crete as the "inventor" of the canon, see: Jean- Baptiste Pitra, Juris Ecclesiastici Graecorum. Historia et monumenta, vol. I, Rome 1868, p. 29; Wilhelm Weyh, "Die Akrostichis in der byzantinischen Kanonesdichtung" in:

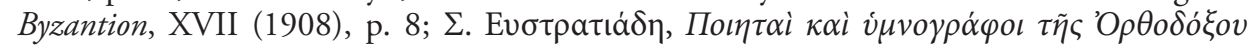


the death of Romanos ${ }^{11}$. In other words, we are concerned with how the typology is present in the new hymnographic production of the eighth century, known under the title of canon, and how the transition from the typology existing in the kontakion to the one in the canon was achieved.

\section{Towards a history of typology in the kontakia of Romanos}

Any researcher who analyzes the typology of Romanos's kontakia is tempted to draw on the article written by R.J. Schork ${ }^{12}$ and the PhD thesis of Roland Joseph Reichmuth ${ }^{13}$. The reason is clear: only these studies directly problematize the way in which Romanos merged the two Testaments in the Person of Christ, through the use of typology. But what do the two fundamental studies for the research of Romanos's typologies aim to present?

The first, in diachronic order of drafting the studies, namely R.J. Schork, shows that the Byzantine Hymnographer uses the Holy Scriptures in three

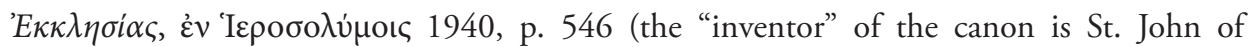

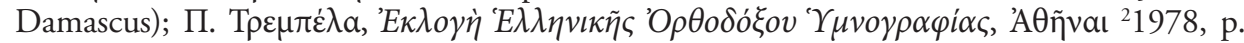

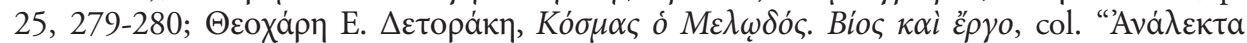

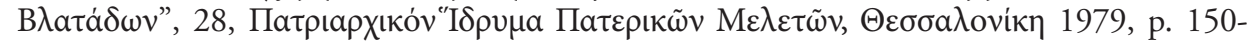
151 (citing ancient and Byzantine sources, it indicates Cosma the Melodist as the "inventor" of the canons consisting of three odes), the line already set in Patrology accepts the Andreian paternity. See, for example, his opinions in: L'Abbé Marin, Les Moines de Constantinople depuis la fondation de la Ville jusqu'a a la mort de Photius (330-898), Paris 1897, p. 487; Karl Krumbacher, Geschichte der Byzantinischen Litteratur von Justinian bis zum Ende des Oströmischen Reiches (527-1453), München ${ }^{2} 1897$, p. 673; Henry Julius Wetenhall Tillyard, Byzantine music and hymnography, London 1923, p. 19; L. Petit, "André de Crète", in: Fernard Cabrol et al. (ed.), Dictionnaire d'Archeologie Chrétienne et de Liturgique, vol. I/1, deuxiéme partie: Amict-Azymes,

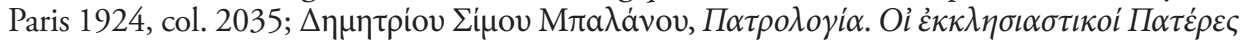

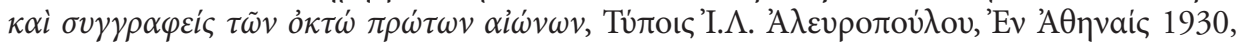
p. 562; Joseph Tixeront, Précis de Patrologie, Paris ${ }^{11} 1934$, p. 412; Basilio Steidle, Patrologia seu Historia Antiquae Litteraturae Ecclesiasticae, Friburg 1937, p. 226; etc.

11 Of course, we derive some information from contemporary studies which indicate Romanos's influence on other hymnographers, including Andrew of Crete, and the relation between the two forms of Byzantine hymnography. See: Egon Wellesz, A History of Byzantine Music and Hymnography, Second Edition, revised and enlarged, Oxford 1962, p. 198245; Mary B. Cunningham, "The reception of Romanos in middle Byzantine Homiletics and Hymnography" in: Dumbarton Oaks Papaers, 62 (2008), p. 251-260; Derek Krueger, "The Great Kanon of Andrew of Crete, the Penitential Bible, and the Liturgical Formation of the Self in the Byzantine Dark Age" in: Brouria Bitton-Ashkelony, Lorenzo Perrone (ed.), Between Personal and Institutional Religion. Self, Doctrine, and Practice in Late Antique Eastern Christianity, col. "Cultural Encounters in Late Antiquity and the Middle Ages", Turnhout 2013, p. 81-90 (republished in: idem, Liturgical Subjects: Christian Ritual, Biblical Narrative and the Formation of the Self in Byzantium, Philadelphia 2014, p. 130-163).

12 R. J. Schork, “Typology”, p. 211-220.

${ }^{13}$ R. J. Reichmuth, Typology, 234 p. 
dimensions: a) the narrative dimension (biblical references that have a direct connection with the action of the hymn); b) lyrical (those short scriptural phrases that have been altered from the original context and accommodated to a new occurrence) and c) allusive (those biblical occurrences linked only to the action of the kontakion to the extent to which they contain characters or events that can be used by the Byzantine poet for the purposes of comparison or contrast) ${ }^{14}$.

Through typology, the events in the Old Testament "seek" their fulfilness in the neo-testamentary texts. Obviously, they will be illuminated and fulfilled in the person of Christ, the Son of God and the Son of Man ${ }^{15}$. According to R. J. Schork, Romanos was definitely aware of the unifying continuity of the divine oikonomia, in which the historical events received complete meaning. However, the Byzantine poet is not making remarks in his works regarding the metaphysical relationship that exists between type and antitype ${ }^{16}$. However, the fundamental thesis of Romanos's typology lies in the reality that Christ's Incarnation substantially changed the history of humankind. Through and within Christ, the events of the New Covenant, otherwise accomplished after a continuous preparation, receive a particular importance ${ }^{17}$. In fact, R.J. Schork states that in the Old Covenant, Christ and His historical activity were presented in shadow or "glass" (1 Co 13:12), while in the New Testament, as soteriological realities ${ }^{18}$. In conclusion, R. Schork points out that:

"the spiritual exegesis in the kontakia of Romanos is built on a foundation of typology - a typology which is generally traditional, fundamentally Christological, predominantly historical, and strikingly poetical a typology which places a strong emphasis on the priority of the second term, the Incarnate Word"19.

Much denser in terms of describing the nuances of Romanos's typologies is Roland Joseph Reichmuth. After showing that the typology has as its main goal the discovery of relationships that are involved both in the belief that the Old Testament points to Christ and the similarities that unite the Old Covenant with the New one $e^{20}$, Reichmuth identifies three categories of

\footnotetext{
${ }^{14}$ R. J. Schork, “Typology”, p. 212-213.

15 Ibidem, p. 215.

16 Ibidem, p. 215.

17 Ibidem, p. 216.

18 Ibidem, p. 217.

19 Ibidem, p. 219.

${ }^{20}$ R. J. Reichmuth, Typology, p. 7-8.
} 
typological images in Romanos's kontakia. The first category is the one of the images from the Old Testament where the typology is mistaken for allegory and where a clear separation between the two species is difficult to achieve. The examples inserted by Reichmuth in support of his theory are taken from the kontakia at Prophet Jonah and Nineveh ( $\left(\varepsilon^{1-10}\right.$ where appears the technical

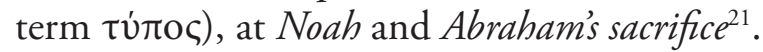

The second typological category is generally limited to the extent of a stanza as is the case of the hand of Thomas, who touches the pierced rib of the Saviour, compared by the Byzantine poet in the second stanza of the kontakion of Thomas touch, with the unburnt pyre in the time of Moses ${ }^{22}$.

The last category of typology actually sums up the allusions that doesn't have any explicit development in Romanos's kontakia (examples: water in the desert, dew from the oven, the rain on Gideon's fleece), though they have Christological connotations ${ }^{23}$. Certainly, according to Reichmuth, the terminology particular to Romanos for the typologies does not only contain the classical $\tau \dot{\pi} \pi \circ \varsigma$, but an entire technical "arse-

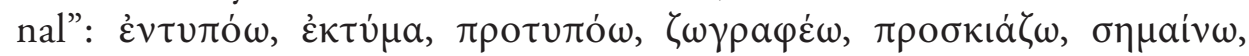

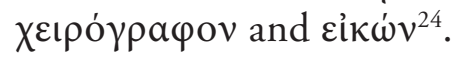

To Reichmuth's vision regarding the typological classifications, Sarah Elizabeth Gador-White opposes, pointing out no less than three methodological issues. First, the distinction between allegory and typology is problematical; Reichmuth's classification is based on the type more than the antitype so that Moses and the events of his life are discussed in a separate chapter about the type expressed through various biblical characters and events; the classification method brings to the foreground the type at the expense of antitype ${ }^{25}$. The stake of the critical analysis made by S.E. Gador-White is founded on the following reality: "Further work remains to be done on why Romanos is using typology" 26 . We believe that this expression can be perceived as interrogative, whose answer we try to provide to the reader in the next paragraph.

Using typology represents the main element of Romanos's Christological expression. Only in a small number of kontakia (seven of them), the

${ }^{21}$ Ibidem, p. 12-13.

22 Ibidem, p. 13-14.

23 Ibidem, p. 14.

24 Ibidem, p. 14; R. J. Schork indicates the complex terminology of Romanos prior to Reichmuth's study. See: R. Schork, “Typology”, p. 215, note 4. Also, a development of the

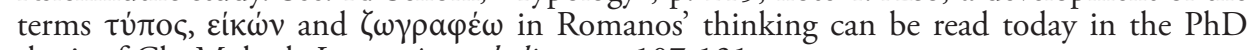
thesis of Ch. Mulard, La pensée symbolique, p. 107-131.

25 S. E. Gador-Whyte, Rhetoric and Ideas, p. 89.

${ }^{26}$ Ibidem, p. 89. 
Byzantine poet does not use his knowledge on typology ${ }^{27}$. But when he does it, the purpose of using typology is to render the Holy Scripture's vivid interpretation and to transmit its message. Of course, Romanos's typology lays emphasis on the historical event as a vivid testimony ${ }^{28}$. According to Greek theologian Ioannis G. Kourembeles

"The typological models of Romanos reveal, on the one hand, the mastery of the Holy Scriptures and his remarkable ability to render even the most subtle detail for the sake of his audience's enjoyment ${ }^{29} \ldots$ Romanos remains, therefore, [anchored] in the truth that the Scripture reveals Christ the Saviour. In this perspective, the typos ( sents itself as less important in the typological models directly related to Christ and His work ${ }^{30 "}$.

Certainly, the typology unites the Old Testament realities with those of the $\mathrm{New}^{31}$; the events in the Old Testament are used as types in the New Covenant precisely to prove the reality that history before the Incarnation of the Logos is a prefiguration of the realities after the Incarnation ${ }^{32}$. As Charles Kannengiesser indicated in the Handbook of Patristic Exegesis, the typology is an image of future things, namely the events of the Christian period. In extenso the history of Israel is a foreshadowing of later Christian events. Only because the past is not restricted to itself, but has a meaning which is important for another perspective of time, a narrative of the Old Testament can be seen as typos of another event. The Old Testament is related to the New Testament by the term typos from an historical point of view ${ }^{33}$. According to patristic tradition a type is a person, an event or an

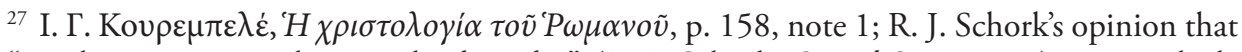
"typology... is everywhere in the kontakia" (R. J. Schork, Sacred Song, p. 15) seems a little bit exaggerated, since Romanos did not use typology for its sake, he used it hoping that the Church's Christological expression will be more intelligible to its audience.

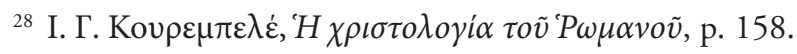

29 According to R. J. Schork, Sacred Song, p. 16: “These instances, and many others, amply illustrate the Melodist's mastery of every aspect of Scripture and his marvelous ability to exploit even the most subtle clue for the enlightenment and delight of his audience".

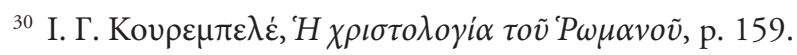

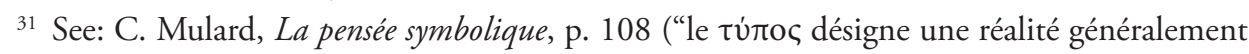
issue de l'Ancien Testament sous le rapport que l'exégèse typologique patristique lui trace avec une autre réalité généralement issue du Nouveau Testament").

32 See: S. E. Gador-Whyte, Rhetoric and Ideas, p. 89-90.

${ }^{33}$ Charles Kannengiesser (ed.), Handbook of Patristic Exegesis: The Bible in Ancient Christianity, vol. I, Brill, Leiden-Boston 2004, p. 220. 
institution which enables that person, event or institution to signify something in the future, in the history where God is acting. The patristic recognition of typos is based on a strictly literary element: Adam or any other person from the Old Testament, be it male or female, can be interpreted as being a significant person for the readers of the New Testament ${ }^{34}$. The New Testament realities go beyond those of the $\mathrm{Old}^{35}$ and this issue is the main characteristic in distinguishing the typology from allegory ${ }^{36}$. In facto, the type needs to have three main elements that differentiate it even more from allegory: a) it must be a true picture of the person or the thing it represents or prefigures; b) it must be of Divine appointment (type and antitype are preordained as constituent parts of the scheme of redemption) and c) a type always prefigures something from the future ${ }^{37}$. In his kontakia, Romanos exploits every opportunity to find the type in Old Testament and to find the parallel reasons between Old and New Testament, in other words the relationship type-antitype. Moreover, the intention of Romanos is to exploit those types and paradigms that he can put in connection with the contemporary events of the Byzantine Empire ${ }^{38}$.

${ }^{34}$ Ibidem, p. 230.

35 S. E. Gador-Whyte, Rhetoric and Ideas, p. 91.

${ }^{36}$ Commonly found in the studies regarding Romanos is the distinction between allegory and typology. To avoid repeating the ideas, we will mention a few fragments that settle this distinction. See: R. J. Reichmuth, Typology, p. 11: "Here, precisely, is where allegory differs from typology: it searches not for connections between two historical phenomena, but for secundary and hidden meanings underlying the primary and obvious meaning of the Scriptural narrative", p. 15: "Allegory, on the other hand, differs from typology because it tends to disregard this historical aspect of type and antitype; it also views the form of the type as a disguise, with no necessary similarity to the reality that lies underneath. It resembles typology, however, since it also is a method of exegesis"; R. J. Schork, Sacred Song, p. 14-15: "allegory... seeks a secondary - sometimes exotically subjective - moral lesson underlying the "historical» level of the primary biblical narrative"; "the so-called literal interpretation of Scripture stresses the history of God with men; in constrast to this sense, allegory as a form of symbolic language, is the basis of every meaning of Scriptures different from the literal one"; C. Kannengiesser (ed.), Handbook of Patristic Exegesis, vol. I, p. 214. On the other hand, authors such as Alexander Korakidis consider that sometimes the distinction between the allegory and typology in Romanos' kontakia is

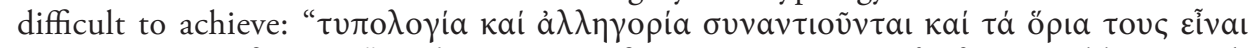

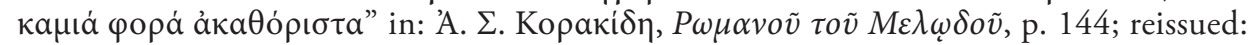
idem, Tó $\pi \varepsilon \rho i ́$, p. 439. About the difference between typology and allegory, see in detail: C. Kannengiesser (ed.), Handbook of Patristic Exegesis, vol. I, p. 212-242 (with contemporary bibliography).

${ }_{37}$ William G. Moorehead, "Type” in: James Orr et al. (ed.), The International Standard Bible Encyclopaedia, V: Socket-Zuzim, Chicago 1915, p. 3029.

38 See: U. H. Eriksen, Drama in the Kontakia, p. 121. 


\section{2. "From Adam to Moses": typological images in Romanos's kontakia}

2.1 Adam is the typological image of Christ, a customary type throughout the patristic thought ${ }^{39}$. Used also with other Fathers of the Church, with the same valence, the face or the image of Adam reflects "the Image of the image" therefore, the image of Christ, the second Adam. This reason is used by Romanos in many contexts, indicating directly Christ as the "second Adam" because He became a man, through the Incarnation ${ }^{40}$. In other words, in the mentality of Romanos one can notice the insistence on the reality that the divine Logos is the subject of Old Testament theophanies in Adam, Abraham and the exodus of the People of Israel. The divine Logos is the subject of the theophanies of the Old-Testament in Adam, also Abraham in the Exodus of the People of Israel ${ }^{41}$. In other words, the divine Logos, the One incarnated in the Trinity recapitulates in the Self the life of Adam and goes beyond $i^{42}$. That is why Romanos

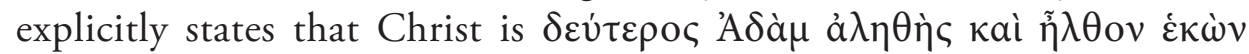

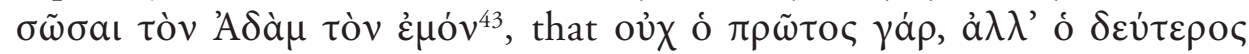
'A $\delta \dot{\alpha} \mu$ Eúav $\dot{\varepsilon} \beta \dot{\alpha} \sigma \tau \alpha \sigma \varepsilon^{44}$, and in the kontakion the Healing of the Leper, the Byzantine poet shows how the new Adam became Adam in the face of un-

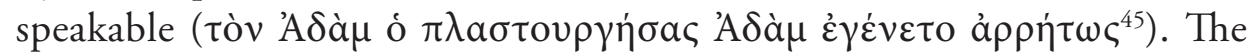
last articulation in Romanos's texts appears to bear witness of the knowledge of the Hebrew mentality of the אדזָ (in Septuagint: A' $\delta a ̀ \mu)$ by the

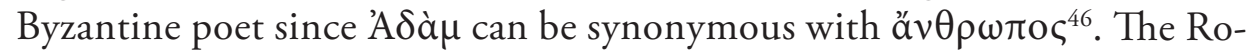
manos theology shows here the reality according to which Adam is the first man of the creation, just as Christ is the first Man of the new creation ${ }^{47}$,

39 J. Grosididier de Matons, Romanos le Mélode et les origines de l'hymnographie, p. 568; Idem, Romanos le Mélode et la origines de la poésie, p. 258. About Adam as typology, see developed extensively in the PhD thesis of R. J. Reichmuth, Typology, p. 33-49.

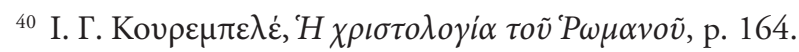

${ }^{41}$ Ibidem, p. 182.

${ }^{42}$ See: S. E. Gador-Whyte, Rhetoric and Ideas, p. 92, 94: "Christ fulfils and surpasses Adam's life", p. 95: "Christ, as the second Adam, corrects the fault of Adam. He fulfils the life of Adam, but he also surpasses it".

${ }^{43}$ J. Grosdidier de Matons (ed.), Romanos le Mélode. Hymnes, vol. 128, XXXIX: $\gamma^{7-8}$, p. 328.

${ }^{44}$ Ibidem, vol. 128, XXXVIII:La ${ }^{9-10}$, p. 300.

${ }^{45}$ Ibidem, vol. 110, XX: $\beta^{3}$, p. 362.

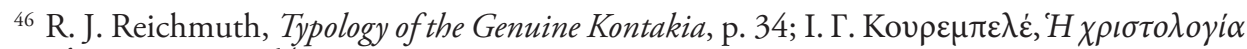

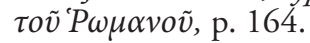

47 S. E. Gador-Whyte, Rhetoric and Ideas, p. 93, 101. 
Founder of this new creation ${ }^{48}$ and Fulfiller of what Adam had to accomplish in Paradise ${ }^{49}$.

In close connection with this typology is the theme of Paradise Lost, where Christ is presented as $\xi \dot{u} \lambda$ ov $\tau \tilde{\eta} \varsigma \zeta \omega \tilde{\eta} \varsigma^{50}$, since the Holy Cross makes life itself shine the light of the tree of life or of consciousness ${ }^{51}$. Also, Adam's failure to guard, in Paradise, the commandment of the post ${ }^{52}$ is repealed by the Person of $\mathrm{Christ}^{53}$, who, through His obedience and fasting for 40 days in the wilderness of Carantana, defeated the erstwhile Adamic hunger ${ }^{54}$. In other words, Romanos clearly indicates that every action of Adam must be redeemed by an act of Christ and that every act of disobedience by Adam is redeemed by the acts of obedience of Christ ${ }^{55}$.

2.2. Eve is the type of Virgin Mary, "the new Eve". José Grosidier of Matons, the French publisher of Romanos's kontakia, sees in the ancestor Eve the maidenhood relationship that connects her to Mary, Mother of God, "Eve... vierge quand elle endanta le Christ, comme Eve était vierge quand elle enfanta le péché" 56 . This relationship is clearly based on Romanos's verses that tell in detail that:

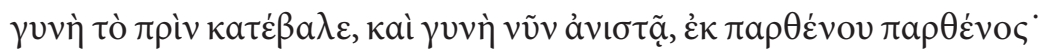

${ }^{48}$ Ibidem, p. 101.

49 Ibidem, p. 95, 96 : "Christ's human life is the fulfilment of Adam's life: he brings it to what it was supposed to be".

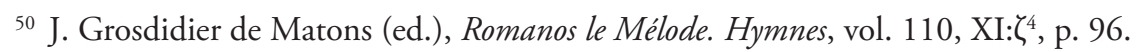

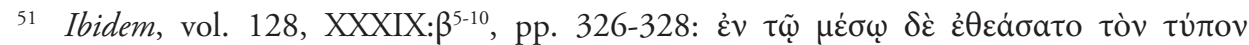

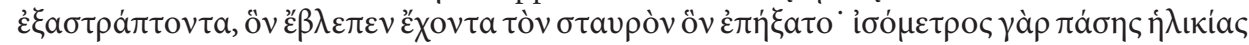

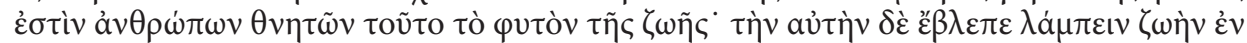

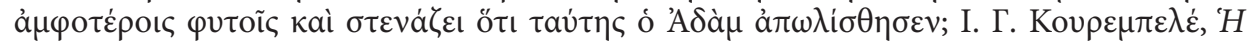

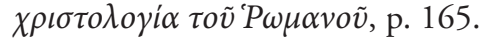

52 José Grosdidier de Matons (ed.), Romanos le Mélode. Hymnes, vol. 99, I: $\delta^{3-6}$, p. 74:

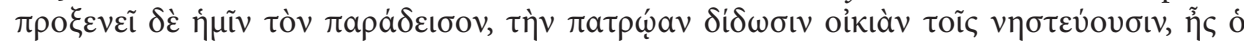

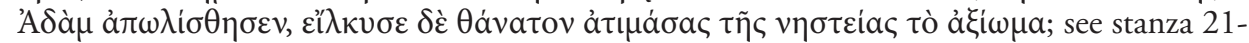
23 of the same kontakion.

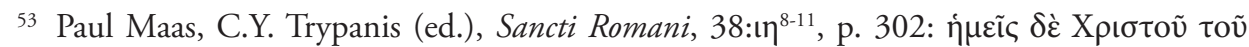

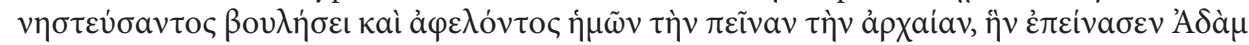

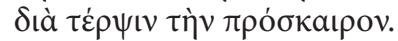

54 J. Grosdidier de Matons (ed.), Romanos le Mélode. Hymnes, vol. 99, II:ı $\zeta^{9-12}$, p. 122-124:

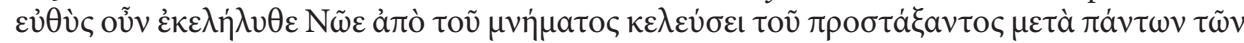

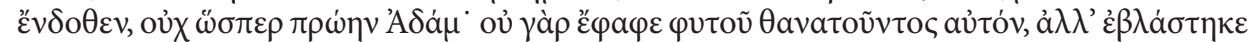

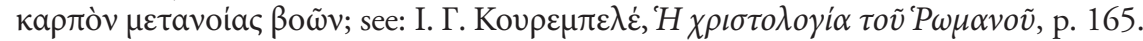

55 S. E. Gador-Whyte, Rhetoric and Ideas, p. 102.

${ }^{56}$ J. Grosididier de Matons, Romanos le Mélode et les origines de l'hymnographie, p. 568; idem, Romanos le Mélode et la origines de la poésie, p. 258. 


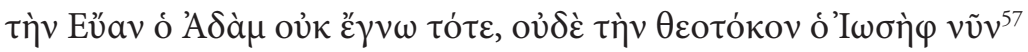

"A woman formerly cast him down, and now a woman raises him up - a virgin from a virgin -

At that time, Adam has not known Eve, nor did Joseph now know the mother of God." 58

In other words, Romanos focuses his attention on the historical reality that through Eve the sin entered into the world, which has brought the death of the human species. Virgin Mary or "the new Eve", after Romanos's language, brings the Life into the world by giving birth, as to her humanity, to the Son of God, the One who called Himself "the Way, the Truth and the Life" $(J n .14: 6)^{59}$. If Eve's disobedience brought death to people, in contrast, through Mary's obedience, who fulfilled the role of $\theta \varepsilon$ có life in the Person of Christ ${ }^{60}$. But the attention of the Byzantine poet focuses also on $\dot{\varepsilon} \kappa \pi \alpha \rho \theta \dot{\varepsilon} v o v \pi \alpha \rho \theta \dot{\varepsilon} v o \varsigma$ formula, formula that actually indicates the reality that Eve, before tasting from the tree was a virgin, just as Mary, through whom the Fruit of blessing was brought, was and will be forever virgin. Therefore, Eve's virginity foreshadows Mary's virginity ${ }^{61}$.

But Eve doesn't have only these typological connotations. Even the special act of her creation, from Adam's rib (Gen. 2: 21-22), symbolizes in Romanos's thinking the very rib of Christ himself that was pierced by the lance and through which Eve was taken again in Paradise ${ }^{62}$. In extenso, therefore, from the rib of the first Adam, Eve came to life, the one called "life", while from the rib of Christ, the "second Adam" or "the true Adam", "it gives a drink and offers a bath, to those who are foul":

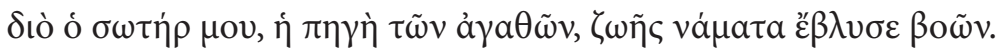

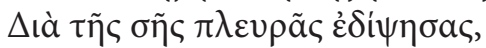

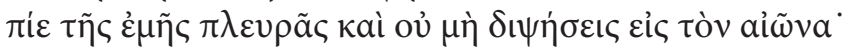

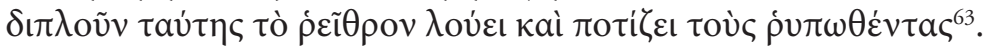

57 J. Grosdidier de Matons (ed.), Romanos le Mélode. Hymnes, vol. 110, XII: $\eta^{3-6}$, p. 124.

${ }^{58}$ M. Carpenter, Kontakia, II, p. 22.

59 See: S. E. Gador-Whyte, Rhetoric and Ideas, p. 96, 101.

${ }^{60}$ Ibidem, p. 97.

61 Ibidem, p. 97.

${ }^{62}$ J. Grosdidier de Matons (ed.), Romanos le Mélode. Hymnes, vol. 128, XXXVIII:ıa ${ }^{4-10}$, p.

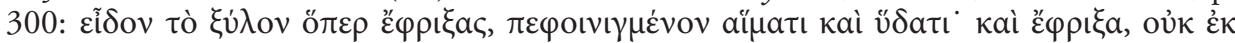

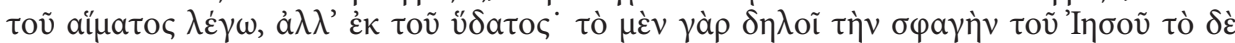

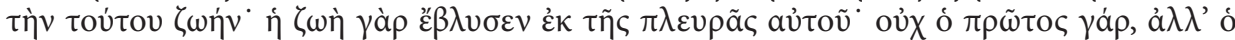

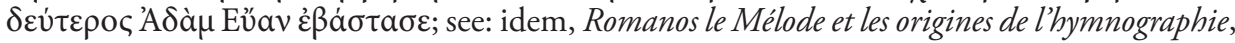
p. 568; idem, Romanos le Mélode et la origins de la poésie, p. 258.

${ }^{63}$ J. Grosdidier de Matons (ed.), Romanos le Mélode. Hymnes, vol. 128, XXXVI:ı ${ }^{4-7}$, p. 224-226. 
"Therefore, my Savior, Fountain of blessings, has caused to gush forth springs of life,

As He says: You have become thirsty through Eve

Drink, then, from my side and you will never thirst

Twofold is the stream: it gives a drink and offers a bath, to those who are foul" ${ }^{4}$.

Also with reference to Eve, but implying a different pattern, namely, "Pilate's wife" Romanos recalls how Christ hurt "the rib" of Pontius

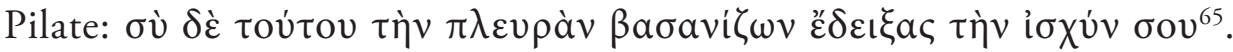
From a dogmatic perspective, in the field of the close relation between soteriology and Christology the great importance becomes understood of the anthropological component that Mary (the second Eve) is the offspring of Adam and becomes follower of Christ, the One from the Trinity Incarnated ${ }^{66}$.

2.3. Closely related to the image of the forefathers is the reality of the terrestrial Paradise with its waters, the reality of the tree of life (or consciousness) and the leather clothes worn by the forefathers after the fall in sin. Certainly, in the reality of the terrestrial Paradise with its waters is encoded the Sacrament of Baptism, Sacrament that can save the lineage of Adam as long as through him fell ill ${ }^{67}$ :

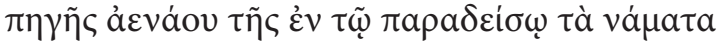

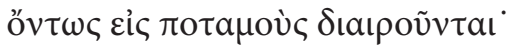

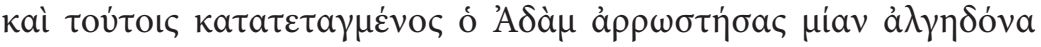

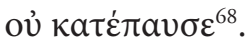

"The streams of water of the ever-flowing Source in Paradise

In truth divide into rivers,

And in them the sickened Adam, as is written,

Did not assuage one pain." ${ }^{69}$

The tree of knowledge or life planted in the middle of the Paradise has a bivalent role: it symbolizes both Christ "the tree of life", which was carried in

\footnotetext{
${ }^{64}$ M. Carpenter, Kontakia, I, p. 213-214.

${ }^{65} \mathrm{~J}$. Grosdidier de Matons (ed.), Romanos le Mélode. Hymnes, vol. 128, XXXVI:เ $\gamma^{6}$, p. 220.

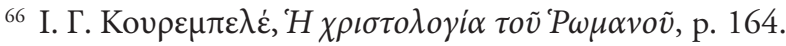

${ }^{67}$ J. Grosididier de Matons, Romanos le Mélode et les origins de l'hymnographie, p. 568; idem, Romanos le Mélode et la origines de la poésie, p. 258.

${ }^{68}$ J. Grosdidier de Matons (ed.), Romanos le Mélode. Hymnes, vol. 283, LII: $\sigma^{1-4}$, p. 350.

${ }^{69}$ M. Carpenter, Kontakia, II, p. 231.
} 
the womb of the Virgin ${ }^{70}$ as well as the Holy Cross ${ }^{71}$; while the leather coats or clothes which were wore by the protoparents after the fall in sin symbolize or are put in relation with the to clouts with which the body of Christ was

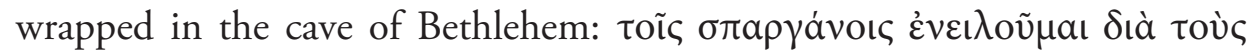

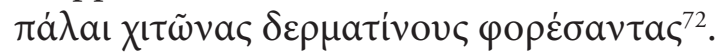

2.4. Abels unjustly death by Cain prefigures for the Byzantine Melodist both the Saviour's death, condemned by Caiaphas as well as the massacre of the 14,000 infants from Bethlehem ${ }^{73}$. Romanos emphasizes in his kontakia the soteriological reality that Abel, by his death, brought to God "a

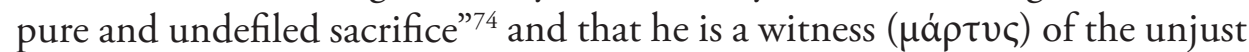
death of which, from the love for the "spiteful people" Christ has suffered:

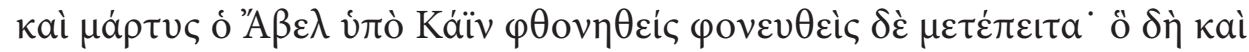

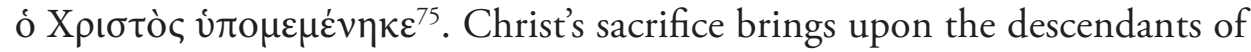
Cain a new "burdening", just as Abel $^{76}$ brought it through his death. In a different kontakion by Romanos, dedicated to Joseph himself, Christ identifies Himself as the "second Abel" who, through His death has thrown the fear, thus "Cains' legacy" 77.

2.5. Enoch is another typological model of Christ, symbolizing Christ's

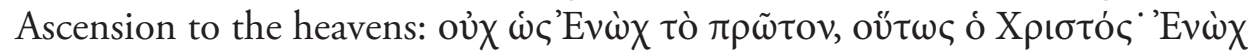

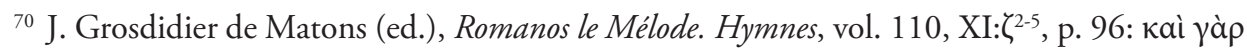

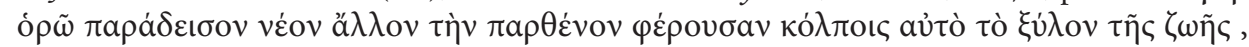

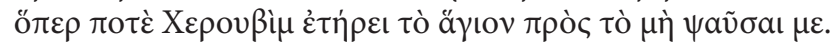

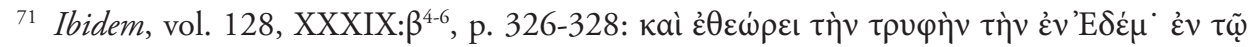

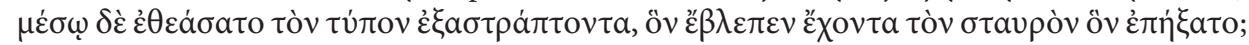

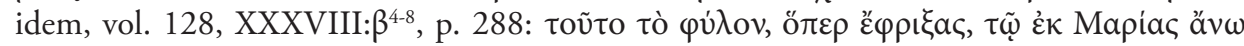

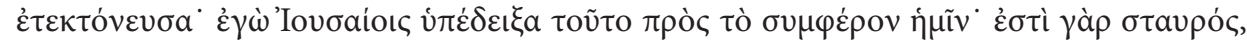

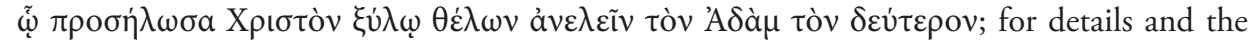
theology of this typology, see: S. E. Gador-Whyte, Rhetoric and Ideas, p. 97-100; U. H. Eriksen, Drama in the Kontakia, p. 221.

${ }^{72}$ J. Grosdidier de Matons (ed.), Romanos le Mélode. Hymnes, vol. 110, XI:I $\delta^{3-4}$, p. 104; see: idem, Romanos le Mélode et les origins de l'hymnographie, p. 568; idem, Romanos le Mélode et la origines de la poésie, p. 258.

${ }^{73}$ Idem, Romanos le Mélode et les origins de l'hymnographie, p. 568; idem, Romanos le Mélode et la origines de la poésie, p. 258; see: R. J. Reichmuth, Typology, p. 186-187.

${ }^{74} \mathrm{~J}$. Grosdidier de Matons (ed.), Romanos le Mélode. Hymnes, vol. 110, XV:ı $\beta^{3}$, p. 218: 'A $\beta \varepsilon \lambda$

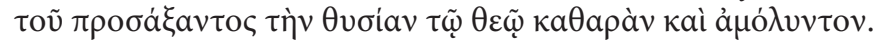

75 Ibidem, vol. 128, XXXVI: $\varepsilon^{4-5}$, p. 208.

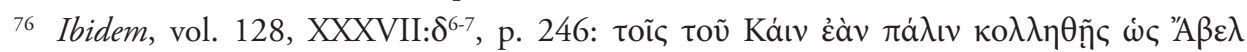

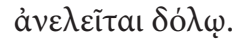

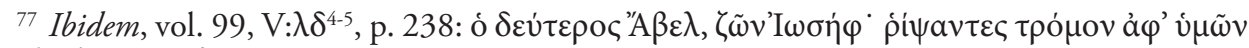

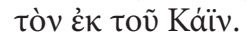




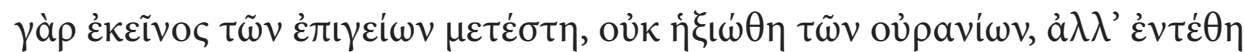

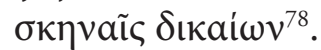

2.6. Much richer in typological meanings is Noah and the ark built by him $^{79}$. If the event of Noah's exit from the ark symbolizes the prefigura-

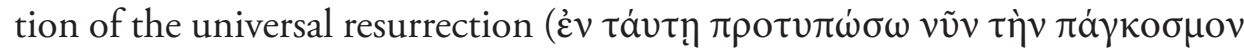
$\left.\dot{\alpha} v \alpha \dot{\sigma} \sigma \alpha \sigma \nu v^{80}\right)$, the ark itself is the symbol of the cross that saved humankind from the divine wrath, a symbol of salvation and restoration ${ }^{81}$. Romanos says

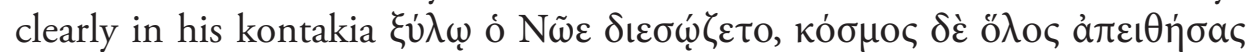
$\omega \lambda \lambda \lambda u \tau 0^{82}$. Also related to Noah and the flood is the sending of a dove over the waters. His return with an olive branch symbolizes the grace of God

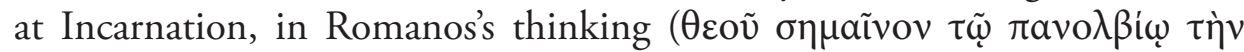
$\varepsilon \dot{\varepsilon} \sigma \pi \lambda \alpha \gamma \chi \chi^{\prime}{ }^{\prime} \alpha \nu \dot{\varepsilon} v \mu v \sigma \tau \eta \rho i\left(\omega^{83}\right)$, but it may also be a prefiguration of Mary Magdalene, who announced to the disciples about the Paschal event ( $\dot{\omega} \varsigma$

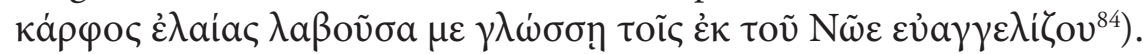

2.7. Sarah, Abraham and Isaac represent other important typological models for the Byzantine Hymnographer. Sarah is mainly related to the issue of sterility, which becomes type in Romanos's hymnography for Anne, the mother of the Virgin Mary:

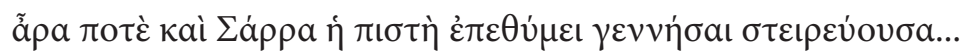

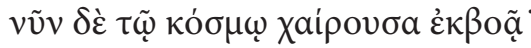

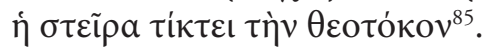

"Did not the faithful Sarah... desire to give birth, even thought she was sterile?

Now, rejoicing, she cries to the world:

The barren woman gives birth to the Mother of God." ${ }^{86}$

When it comes to Abraham, the interpretative facets are more complex: he is both the exponent of Constantine the Great and also of God the

${ }^{78}$ Ibidem, vol. 283, XLVIII:I $\delta^{6-8}$, p. 162.

${ }^{79}$ For details, see: R. J. Reichmuth, Typology, p. 134-138.

${ }^{80}$ J. Grosdidier de Matons (ed.), Romanos le Mélode. Hymnes, vol. 99, II: ${ }^{8}$, p. 114.

81 See: S. E. Gador-Whyte, Rhetoric and Ideas, p. 101.

${ }^{82}$ J. Grosdidier de Matons (ed.), Romanos le Mélode. Hymnes, vol. 128, XXXVIII:เ $\gamma^{4-5}$, p. 302.

${ }^{83}$ Ibidem, vol. 99, II:L५ , p. 122.

84 Ibidem, vol. 128, XL:I $\delta^{10-11}$, p. 404; see: idem, Romanos le Mélode et les origines de l'hymnographie, p. 568; idem, Romanos le Mélode et la origins de la poésie, p. 258.

85 Paul Maas, C.Y. Trypanis (ed.), Sancti Romani, 35: $\eta^{1 / 5-6}$, p. 279.; see: R. J. Reichmuth, Typology, p. 176, also, the sterility of Sarah may be put in connection with that of Ana, the mother of Samuel, p. 175-176.

${ }^{86}$ M. Carpenter, Kontakia, II, p. 4. 
Father, who sacrificed His own Son for the salvation of the world. If the first reference has as a common element number 318 (the 318 fighters whom Abraham took for Lot's release and the image of the 318 Fathers participating at the First Ecumenical Council of Nicaea) ${ }^{87}$, the second reference is strictly theological. Romanos outlines, through his dramatic verses, the scene of Isaac's sacrifice by his own father. Abraham resembles God the Father, since he didn't regret the sacrifice of his own son for God. In the same manner, neither does the supreme Father regret to offer to slaughter his own son, symbolized by Isaac ${ }^{88}$, "the Giver of blessings and Savior of our souls", for ever born from Him:

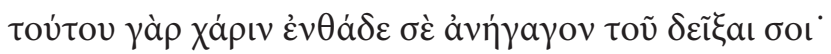

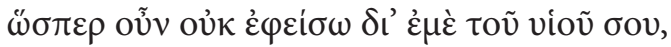

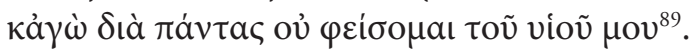

"It is for this reason that I had you ascend here, to show you/.

Just as you did not spare your son because of me/,

Just so, I shall not spare my son because of all men." ${ }^{\text {90 }}$

The mystery of the cross is revealed by the wood worn by Isaac on his shoulders, after the image of Christ, who carried the cross on his shoulders, to

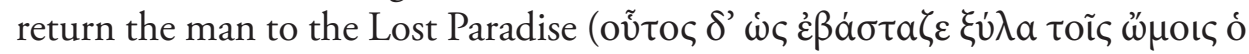

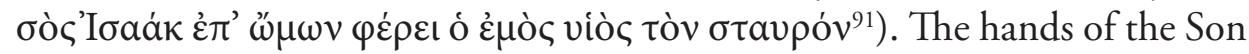
of God, which stretch on the cross, are symbolized by the horns of the ram caught in the branches of the shrub ${ }^{92}$.

2.8. With regard to characters such as Esau, Jacob and Rebecca, Romanos states directly that the sons of Isaac are the "prototypes of the future"

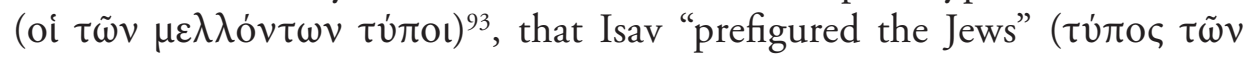

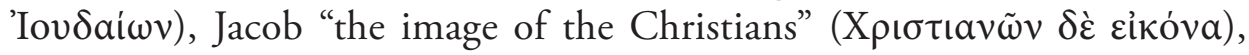

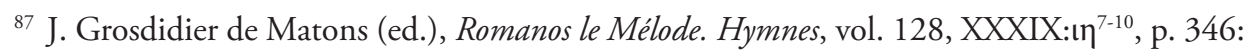

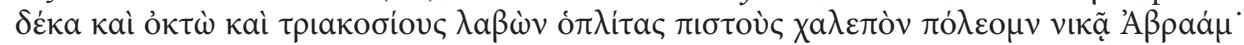

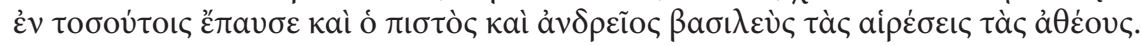

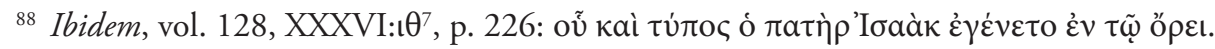

${ }^{89}$ Ibidem, vol. 99, III: $\kappa \beta^{5-7}$, p. 160.

${ }_{90}$ M. Carpenter, Kontakia, II, p. 69.

${ }^{91}$ J. Grosdidier de Matons (ed.), Romanos le Mélode. Hymnes, vol. 99, III: $\kappa \gamma^{1-2}$, p. 162; see

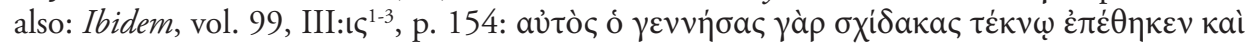

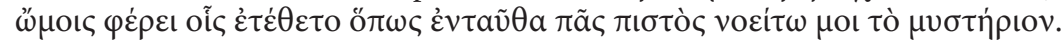

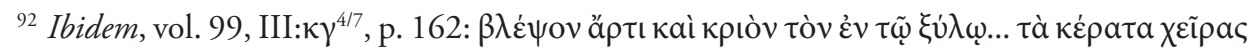

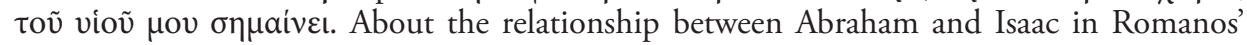
typology, see extensively: R. J. Reichmuth, Typology, p. 138-144.

${ }^{93}$ J. Grosdidier de Matons (ed.), Romanos le Mélode. Hymnes, vol. 99, IV: $\beta^{1}$, p. 174. 


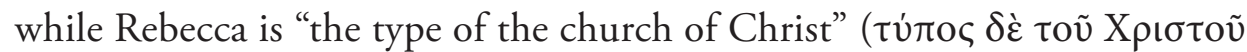

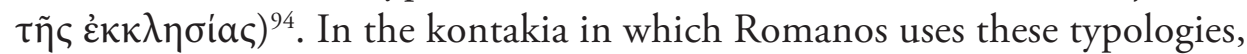
he has the central intent of making the audience understand the theological content of these images ${ }^{95}$. Also, the salt by which the food of Isaac was seasoned prefigures Christ, who keeps Christians clean against decay ${ }^{96}$, while the blessing brought on Jacob symbolizes the coming of Christ, the One "who appeared and illumined all things":

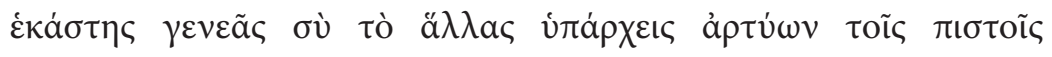
ảdiá $\varphi \theta$ o $\rho$ ov $\beta \rho \tilde{\omega} \mu \alpha$,

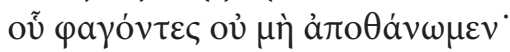

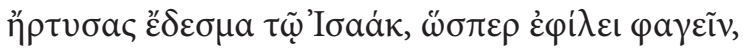

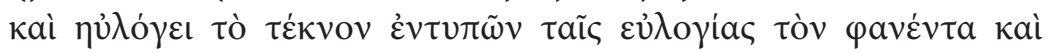
$\varphi \omega \tau i \sigma \alpha \nu \tau \alpha \pi \dot{\alpha} v \tau \alpha^{97}$.

"You are the salt of each generation/,

Seasoning for the faithful the food which is incorruptible/.

If we eat it, we shall not die/.

You seasoned a dish for Isaac from which he loved to eat/,

And he blessed his son, symbolizing in his blessings/

The One who appeared and illumined all things." ${ }^{\prime}$

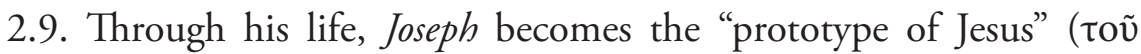

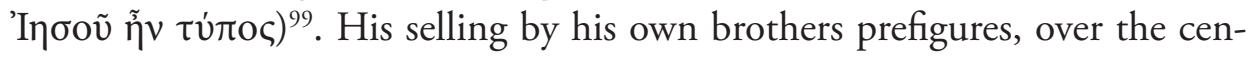
turies, the betrayal of Judas ${ }^{100}$, while the dinner at which Joseph's brothers decide his selling symbolizes the Last Supper ${ }^{101}$. Also, Joseph symbolizes both

${ }^{94}$ Ibidem, vol. 99, IV:I $\theta^{3-4 / 8}$, p. 192; idem, Romanos le Mélode et les origines de l'hymnographie, p. 569; idem, Romanos le Mélode et la origins de la poésie, p. 259; R. J. Reichmuth, Typology, p. 144-148.

${ }^{95}$ U. H. Eriksen, Drama in the Kontakia, p. 256.

${ }^{96}$ J. Grosididier de Matons, Romanos le Mélode et les origines de l'hymnographie, p. 569; idem, Romanos le Mélode et la origins de la poésie, p. 259.

${ }^{97}$ Idem, Romanos le Mélode. Hymnes, vol. 110, XVII:I ${ }^{5-10}$, p. 286-288.

${ }^{98}$ M. Carpenter, Kontakia, I, p. 64.

99 J. Grosdidier de Matons (ed.), Romanos le Mélode. Hymnes, vol. 99, V: $\mathbf{a}^{7}$,p. 204; vol. 128, XXXIII: $\theta^{6}$,p. 92. About this typology, see extensively: R. J. Reichmuth, Typology, p. $148-156$.

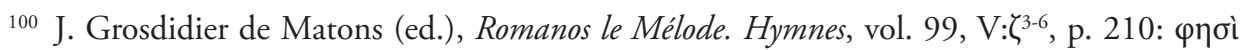

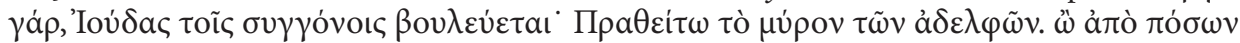


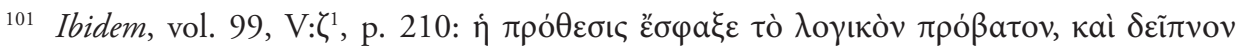
$\pi \alpha \rho \dot{\varepsilon} \theta \eta \kappa a v$. 
the "immortal water" promised to the woman of Samaria ${ }^{102}$ and the resurrection of Christ ${ }^{103}$.

2.10. The Old Testament character with the most typologies in Romanos's kontakia is Moses. The history of the three typological images ${ }^{104}$ begins with Moses's salvation from the Nile waters that prefigures Christ's salvation in Romanos's theology by fleeing from Egypt:

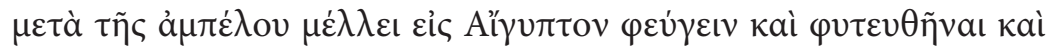

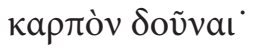

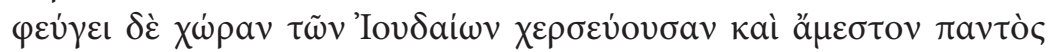

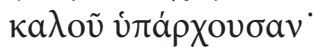

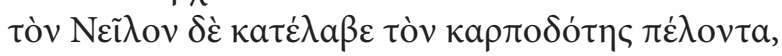

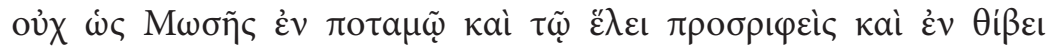
$\varphi v \lambda \alpha \chi \theta \varepsilon i \varsigma^{105}$.

"Is going to flee to Egypt along with the vine/

To be planted there and bring forth fruit -

Flee to the land of the Jews/,

Arid and barren of anything beautiful/,

And arrive at the Nile, which is fertile -

Not as Moses on the river, thrown in the marsh, protected

by a wicker basket." 106

The Byzantine hymnographer is concerned with presenting the typologies in relation to Moses in an escalating manner and, moreover, even chronologically. Thus, the calling of Moses by God, through the burning bush symbolizes the Virgin Mary, who will carry in her womb the Son-Man and the Son of God. Hereby, Romanos states with much emphasis in the kontakion the Annunciation:

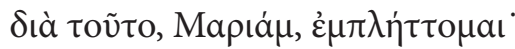

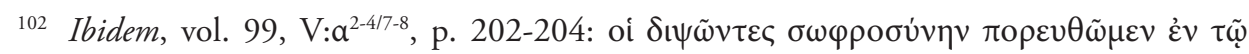

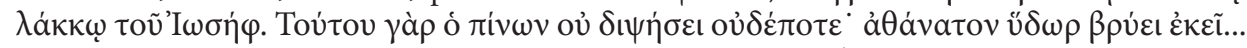

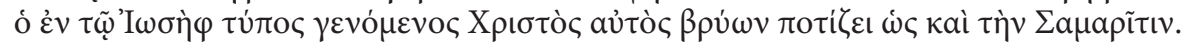

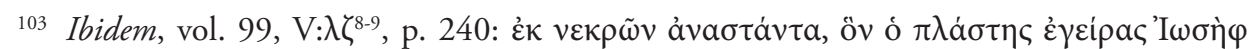

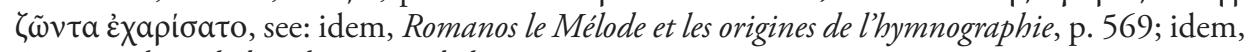
Romanos le Mélode et la origins de la poésie, p. 259.

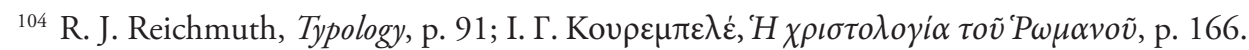
Related to Moses, we believe that it requires an attainment of all the typological forms from the 23 kontakia by Romanos in which occures the face of Moses. More opinions regarding Moses as typology, see extensively: R. J. Reichmuth, Typology, p. 91-133.

105 J. Grosdidier de Matons (ed.), Romanos le Mélode. Hymnes, vol. 110, XV:เદe-10, p. 222, see:

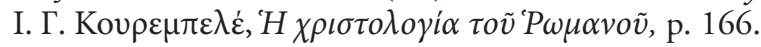

${ }^{106}$ M. Carpenter, Kontakia, I, p. 32. 


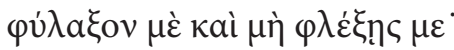

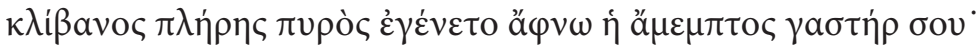

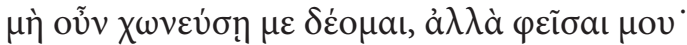

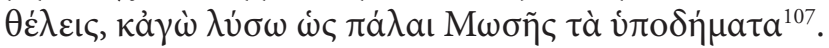

"And so, Mary, I am struck with amazement/.

Protect me and do not consume me/!

Your chaste womb has suddenly become a furnace full of fire/;

Then do not, I beg of you, melt me, but spare me/.

You wish that I too, like Moses long ago, take off my sandals." ${ }^{108}$

But Romanos gives the burning bush seen by Moses another theological connotation: it is likened to Christ's rib, which is like the "burning flame"

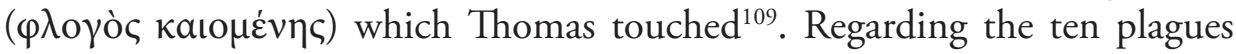
directed against Egypt, they do not have in Romanos's thinking an exhaustive typological refference. For Romanos only the first plague, namely, the turning of water into blood (Isaiah 7: 14-18) has a typological value indicating the miracle of Cana of Galilee, where Christ turned water into wine:

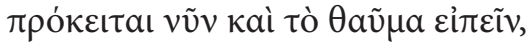

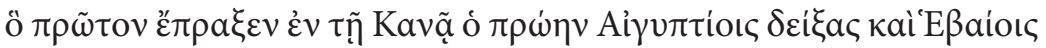

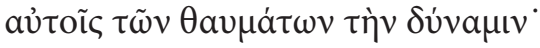

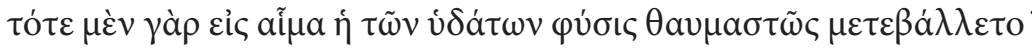

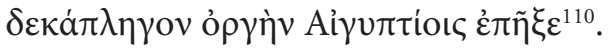

"Now we propose to tell of a miracle the one which He performed in Cana/, He who first revealed to the Egyptians and to the Hebrews themselves the power of miracles/;

For at that time, the nature of the waters was miraculously changed to blood/.

He vented His anger on the Egyptians in ten plagues." 111

But Romanos does not stop only at these moments. He develops his Christological typologies and correlates them with the passing of the Jews

107 J. Grosdidier de Matons (ed.), Romanos le Mélode. Hymnes, vol. 110, IX:เعe-8, p. 36;

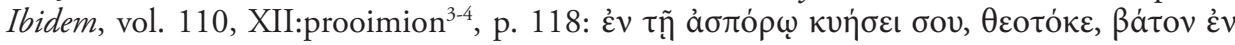

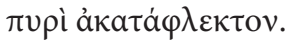

${ }^{108}$ M. Carpenter, Kontakia, II, p. 15-16.

109 J. Grosdidier de Matons (ed.), Romanos le Mélode. Hymnes, vol. 283, XLVI: $\beta^{1-4}$, p. 34:

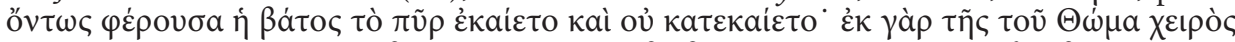

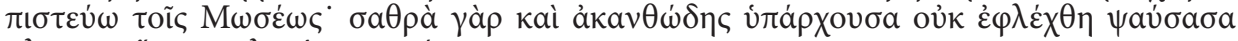

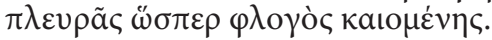

110 Ibidem, vol. 110, XVIII: $\delta^{1-5}$, p. 304.

${ }^{111}$ M. Carpenter, Kontakia, I, p. 69. 
through the Red Sea, with their wanderings through wilderness, with the tense moments from this journey, precisely to underline the miraculous intervention of the unbodied divine Logos. The first event, namely the passing of the Jews through the Red Sea, symbolizes for the Byzantine Hymnographer "the disarming of hell" because, through the death and resurrection of Christ, hell is "depleted" and the man passes from death to life:

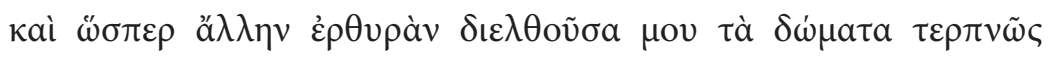

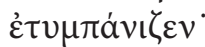

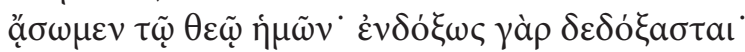

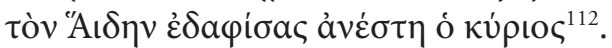

"And coming across my domain like another Red Sea, she joyfully beat the drum/:

Let us praise our God, for He has been gloriously glorified/, Having demolished Hades, the Lord is risen." 113

Moreover, this crossing and the seeing of the Red Sea as a land "and then sea again" is understood as the paradox of the birth as a human of the divine Logos: the Virgin who will give birth, will remain virgin after birth $(\pi \tilde{\omega} \varsigma$

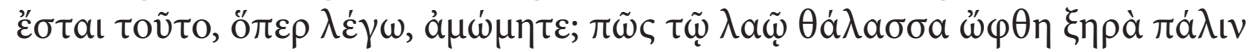

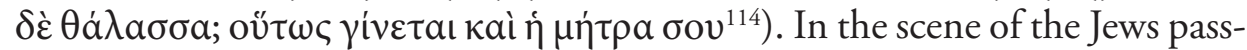
ing through the Red Sea, Moses becomes the mediator of God and co-par-

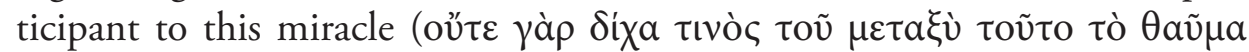

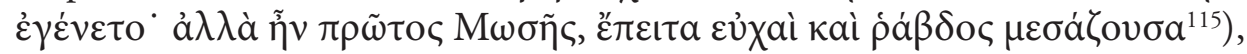
just as Mary becomes co-participant in the unspeakable mystery of the Incarnation of the Lord.

Moses's staff is the symbol of the Holy Cross in Romanos's theology. In the description of the events, Romanos is not a (simple) preacher or writer, but a writer-theologian who theologizes ${ }^{116}$. He is concerned with "dramatiz-

112 J. Grosdidier de Matons (ed.), Romanos le Mélode. Hymnes, vol. 128, XLII:ıa ${ }^{5-8}$, p. 470.

113 M. Carpenter, Kontakia, I, p. 267.

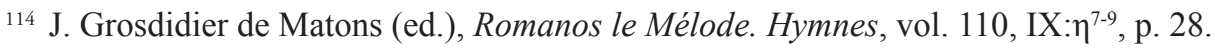

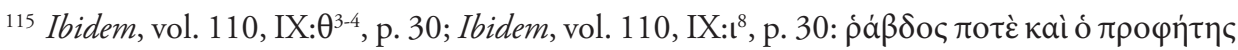

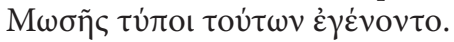

116 There are, unfortunately, many voices that see in Romanos only the philological aspects rather than his ability to be a theologian. See, for example, the contemporary opinion of Ch. Mulard, La pensée symbolique, p. 110: "Romanos est avant tout prédicateur et poète, et très peu théologien". We believe that such views, expressed especially for the sake of the word, take away Melodist's great talent to translate, through poetry, the drama in the dialogue between man and God. Also, we believe that the opinion of the Greek theologian Ioannis G. Kourembeles points out very well how the contemporary study of Romanos

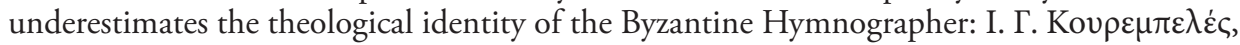


ing", through dialogue, the biblical events and "loading" them with theological nuances. Thus, the wood that will grow and by which the people of Israel will be led to freedom is in Romanos's thinking the symbol of the Cross. If in the old Covenant, through the staff, the people were led to freedom, in the new Covenant, the entire people of Christ are led to the long-ago lost Paradise $^{117}$. This theological truth is expressed by Romanos in the following verses:

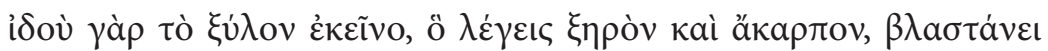
карто́v,

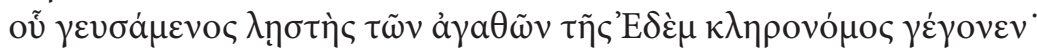

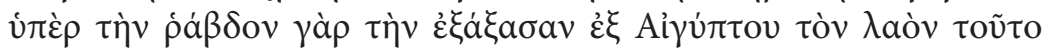

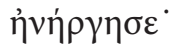

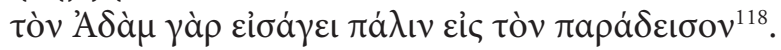

"For, lo, that wood which you call dry and sterile/

Is blossoming into fruit at whose taste the robber/

Has become an heir to the joys of Eden/.

Beyond the wand which brought the people/

Out of Egypt, this wood has been active/,

For it leads Adam again into Paradise." 119

Romanos has the same reference in the kontakion On the Victory of the

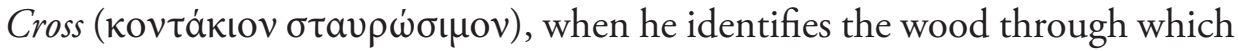
Moses sweetened the water in Mara (Exod. 15: 23-25), with the Holy Cross:

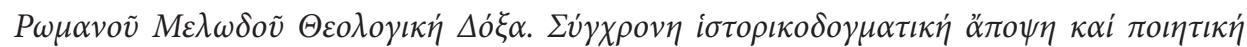

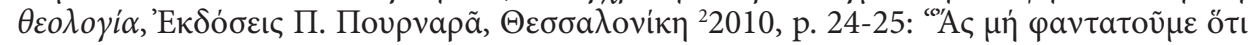

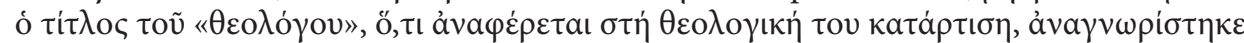

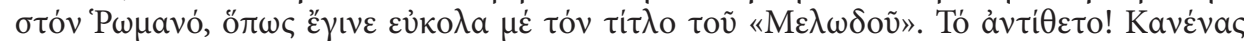

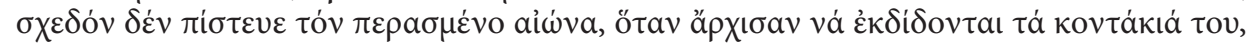

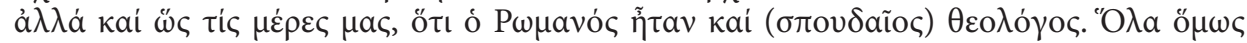

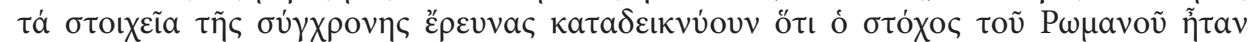

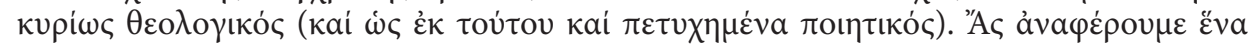

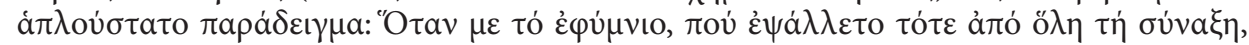

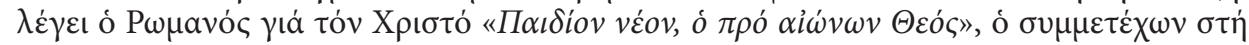

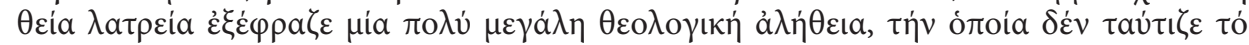

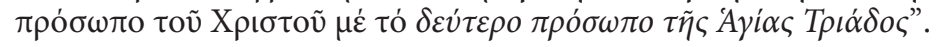

117 J. Grosididier de Matons, Romanos le Mélode et les origines de l'hymnographie, p. 569; idem, Romanos le Mélode et la origins de la poésie, p. 259.

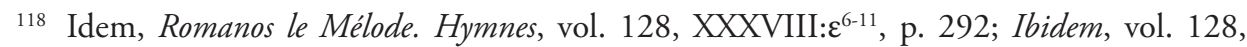

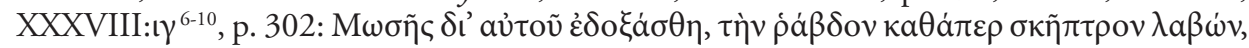

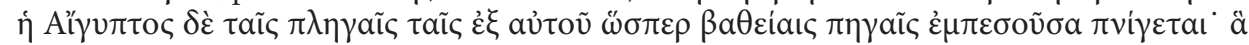

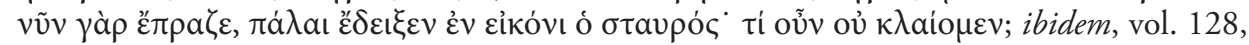

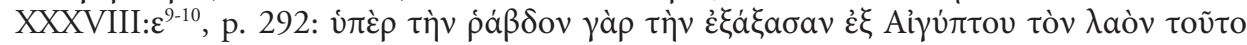

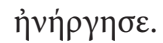

119 M. Carpenter, Kontakia, I, p. 232. 


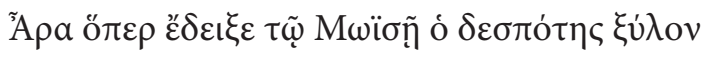

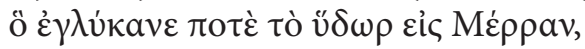

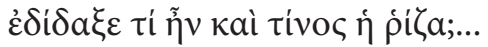

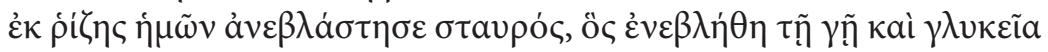

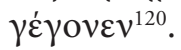

"The Lord showed Moses the wood/

Which sweetened the water at Marah/.

$\mathrm{He}$ did not teach him, did $\mathrm{He}$, what it was, and of what it was the $\operatorname{root} /$ ?...

From our root; and it has become sweet." ${ }^{121}$

In the image in which Moses hits the rock with the staff, from which water sprang, Romanos perceives Christ himself as "the river in the desert"

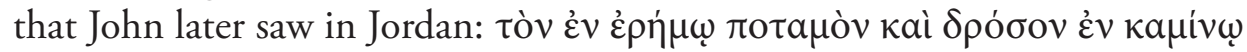

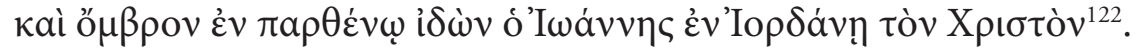

Other verses from Romanos's kontakia led the Old Testament events to the act of birth of the Saviour. Thus, the passing of the Jews through the wilderness and their leading by Moses and the pillar of fire prefigures the leading of the Magi, "from Chaldea" ( $\dot{\varepsilon} \kappa \mathrm{X} \alpha \lambda \delta a i \omega v)$, by the star to Bethlehem, to the scene of birth. The one who guided the Hebrews in the ancient times through the wilderness, by the pillar of fire, is the One who now, in the new times, in New Testament times, leads the Magi to the shabby crib in Bethlehem:

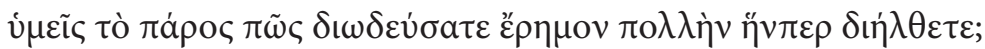

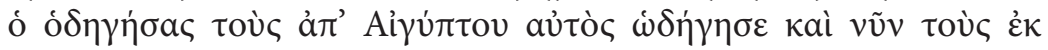

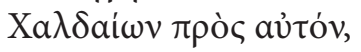

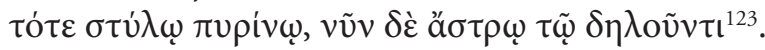

"How did you travel through the great desert which you traversed?/

The One who led them out of Egypt is the One who has just guided the men from Chaldea to Him,

Formerly, it was with a pillar of fire; now with a star to reveal." 124

\footnotetext{
${ }^{120}$ J. Grosdidier de Matons (ed.), Romanos le Mélode. Hymnes, vol. 128, XXXVIII:เE $\varepsilon^{1-3 / 7-8}$, p. 304-306.

${ }^{121}$ M. Carpenter, Kontakia, I, p. 236.

122 J. Grosdidier de Matons (ed.), Romanos le Mélode. Hymnes, vol. 110, XVI: $\delta^{1-2}$, p. 240;

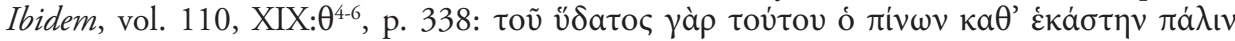

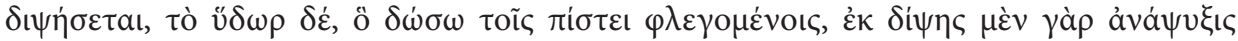

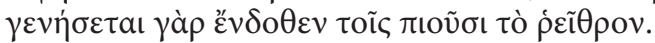

123 Ibidem, vol. 110, X:ı $\eta^{4-9}$, p. 68-70.

${ }^{124}$ M. Carpenter, Kontakia, I, p. 9-10.
} 
But the pillar of fire is also in the Melodist's view the column of the flagellation that Christ "endured the lash... nude and stretched out on a pillar". In the 14th stanza from the kontakion on the Passion of the Lord, Romanos deeply expresses this theological truth which he unites with the pillar of fire and with the Jewish journey through the wilderness:

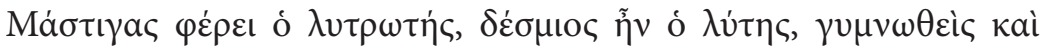

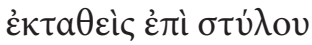

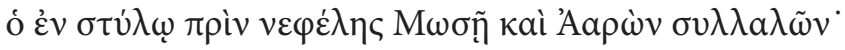

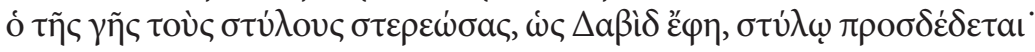

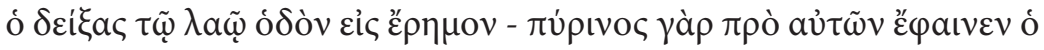

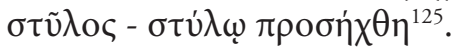

"The Redeemer endured the lash; the Deliverer was in chains, nude and stretched out on a pillar/,

Is He who in a pillar of cloud formerly spoke to Moses and Aaron/.

He who established the pillars of the earth, as David said, is fastened to a pillar/.

He who showed the people the road in the desert, (for the pillar of fire appeared before them), He has been attached to a pillar." 126

Returning to the theme of Christ's birth, Romanos seeks a different prefiguration in the images of the Old Testament. This time, the vision of the Byzantine Hymnographer extends to the manna from the wilderness, in which he notices the prefiguration of birth with body of the divine Logos from the womb of the Virgin:

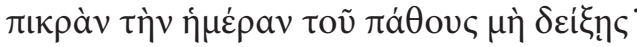

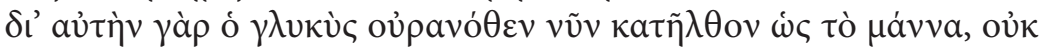

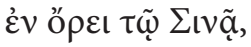

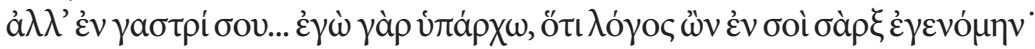

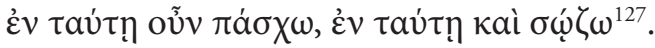

"Do not consider the day of suffering a bitter one -

That day for which I came down from Heaven like the manna-

Not on Mount Sinai but in thy womb...

Consider the meaning, O Holy One, the mountain formed like cheese/.

In it I suffer and in it I save." 128

${ }^{125}$ J. Grosdidier de Matons (ed.), Romanos le Mélode. Hymnes, vol. 128, XXXVI:ı ${ }^{1-6}$, p. 220.

${ }^{126}$ M. Carpenter, Kontakia, I, p. 212.

${ }^{127}$ J. Grosdidier de Matons (ed.), Romanos le Mélode. Hymnes, vol. 128, XXXV: $\varsigma^{1-3 / 6-7}$, p. 166-

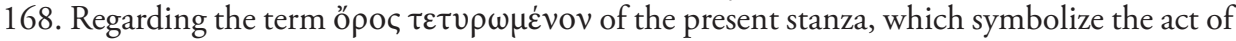
conception in the womb of the Virgin, see ibidem, vol. 128, p. 167, note 3.

${ }^{128}$ M. Carpenter, Kontakia, I, p. 198. 
Romanos's concern is not to "transform" Moses in a "common" character, taken after already known "patterns" in the previous patristic writings. $\mathrm{He}$ seeks in Moses a different typological dimension, one that links the Old Testament character with the future martyrs of Christ. In the second hymn sacred to the 40 Martyrs, Romanos describes how the opposition of Moses against Amalek becomes model in the fight of the martyrs against the opponents of God. He states, therefore, highly expressive that:

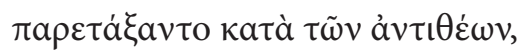

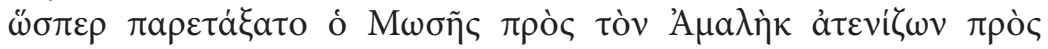

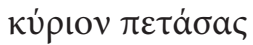

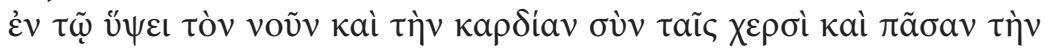
aĭ $\sigma \eta\rceil \iota^{\circ} . .$.

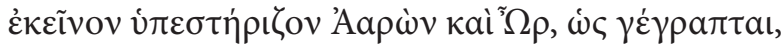

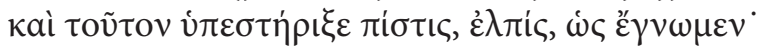

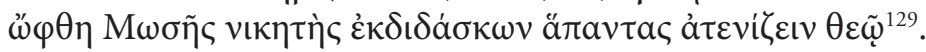

"They were drawn up against the godless/, Just as Moses was drawn up against Amalek. As he gazed at the Lord/.

Reached on high with mind and heart/, And with all his feeling, he raised his hands/;

And as he stretched out his hands and his heart.../ He was almost revealed/.

As it is written, Aaron and Or help up his hands/, And faith and hope supported him, as we know/.

Moses was seen as victor, since he taught all men to reach up to God." ${ }^{130}$

Mount Sinai seems to be for the Byzantine Hymnographer just a historical reference: it is the place where Moses received the theophany and where the old Law was taught to him. But Romanos's preference to "graft" the events of the Old Testament on the New Testament is specific to his style: if Sinai is the mountain where Moses saw God through the unburnt bush, the Mount of Olives is where Christ himself ascends to heaven and sends to all those who will believe in Him His grace. He states, therefore:

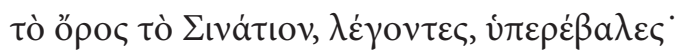

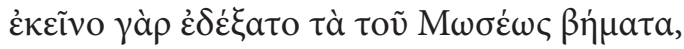

$\sigma u ̀ \delta$ àे

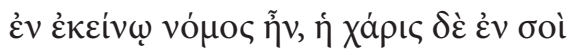

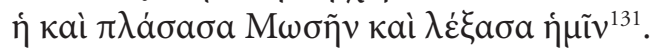

129 Paul Maas/ C.Y. Trypanis (ed.), Sancti Romani, 58:ıa ${ }^{2-11}$, p. 501.

${ }^{130}$ M. Carpenter, Kontakia, II, p. 286.

${ }^{131}$ J. Grosdidier de Matons (ed.), Romanos le Mélode. Hymnes, vol. 283, XLVIII:ı $\zeta^{9-13}$, p. 168. 
"They said: You have surpassed Mount Sinai;

for it became the speaker's platform for Moses' words/,

But you, for the words of Christ/.

The former was the law; but the grace is in Thee/,

The same grace which created Moses." 132

Clearly, a central episode in the life of the Saviour, highlighted by Romanos by using the typology, is the entry into Jerusalem. The Hymnographer is not concerned with the chronological account of the event, as neither with the simple rendering of the soteriological scene. In the scene which Romanos creates for his contemporaries, having as central characters Christ and the Hebrews, Moses is remembered as a decisive character in the salvation of the chosen people from Egyptian slavery. The words addressed by Romanos to the Jews, otherwise unflattering, target the typology between Moses and Christ: just as they had forgotten Moses, even though he freed them from slavery, the same with Christ, the One who has freed us all from the dead, the One who they forgot in a few days demanding his crucifixion. "Friends of Belial", as the Hymnographer calls the Hebrews, knew neither Moses, nor Christ:

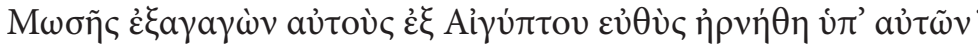

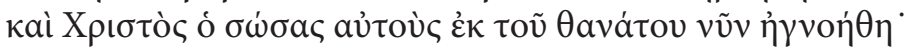

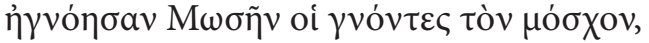

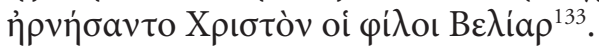

"When Moses led them out of Egypt, immediately he was denied by them/.

And Christ who saved them from death, was not known/!

They did not know Moses who knew the calf/;

Those who were friends of Belial denied Christ." ${ }^{134}$

Also related to the time of Moses is the rod of Aaron, his brother, with the golden bowl in which was kept the hand from the Ark of the Covenant and also the scapegoat sent in the wilderness for the forgiveness of sins. In Romanos interpretation, Aaron's staff that grew symbolizes the conception of Christ without seed from the womb of the Virgin ${ }^{135}$, while "the urn of gold

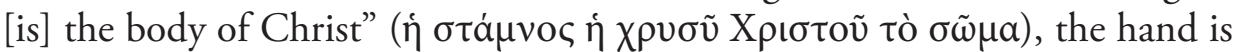

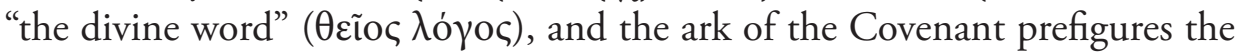

\footnotetext{
132 M. Carpenter, Kontakia, I, p. 357.

133 J. Grosdidier de Matons (ed.), Romanos le Mélode. Hymnes, vol. 128, XXXII:ع $\varepsilon^{5-8}$, p. 36.

${ }^{134}$ M. Carpenter, Kontakia, I, p. 161.

135 J. Grosdidier de Matons (ed.), Romanos le Mélode. Hymnes, vol. 110, XII:prooimion ${ }^{3-5}$,

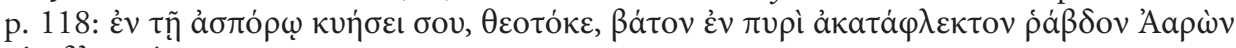

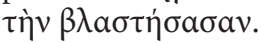




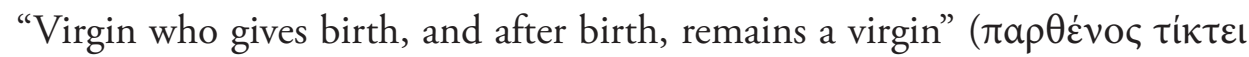

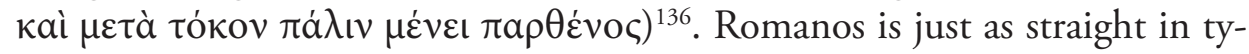
pological expression when talking about the lamb sent in the wilderness on the occasion of the redemption days ( $L v 4: 21$ sq.). In his kontakion on the

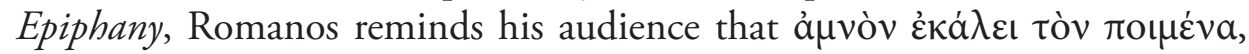

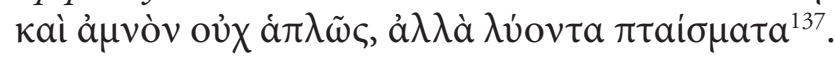

\section{3. "From Adam to Moses": typological images in the Great Canon of Andrew of Crete}

A study to analyze the typologies present in the Great Canon of Andrew of Crete ${ }^{138}$ is still lacking in the specialized literature. However, we tried to show several aspects in our Ph.D. thesis dedicated to the dogmatic Teaching of the Great Canon ${ }^{139}$. Our ideas on the way Andrew of Crete uses typology in his fundamental work were based on the laconic references found in the comments of Acacius the Sabaite ${ }^{140}$ and John of Lind ${ }^{141}$ and in contemporary literature in the studies of Pannayotis Nellas ${ }^{142}$, Olivier Clément ${ }^{143}$, Simeon Koutsas ${ }^{144}$, Job Getcha ${ }^{145}$

${ }^{136}$ Ibidem, vol. 110, XII: $\gamma^{5-7}$, p. 122. About the typologies regarding Virgin Mary, see: A. $\Sigma$.

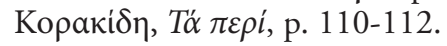

137 J. Grosdidier de Matons (ed.), Romanos le Mélode. Hymnes, vol. 110, XVII:ı $\gamma^{1-2}$, p. 286.

${ }^{138}$ Due to the lack of the critical edition of the Great Canon we used the original Greek:

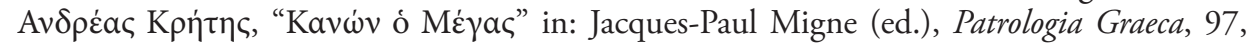
1330D-1386C.

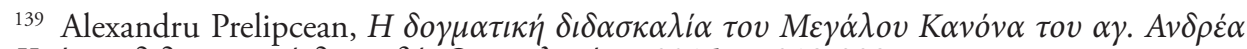

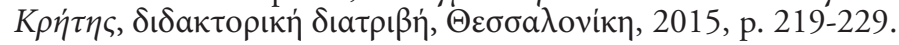

${ }_{140}$ Critical edition: Antonia Giannouli, Die beiden byzantinischen Kommentare zum Großen Kanon des Andreas von Kreta. Eine quellenkritische und literaturhistorische Studie, Wien 2007.

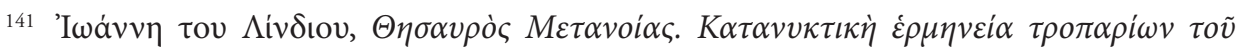

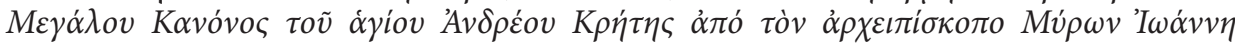

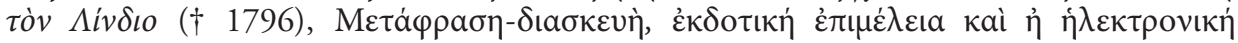

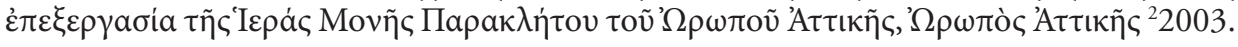

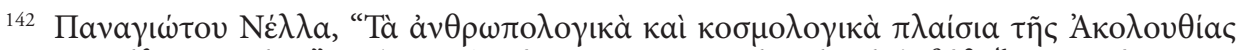

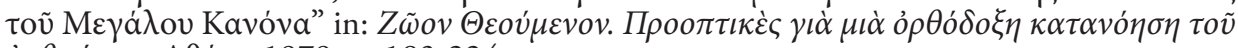

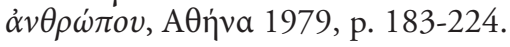

143 Olivier Clément, Le chant des larmes. Essai sur le repéntir. Suivi de la traduction du poème sur le repentir par saint André de Crète, Paris 1982; idem, "Notes sur le Grand Canon de Saint André de Crète" in: Contacts, XXXII (1980), 3, p. 206-234, 294-330.

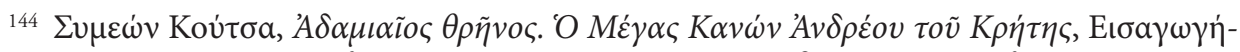

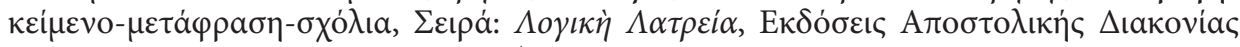

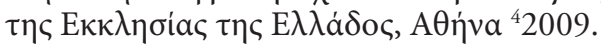

${ }^{145}$ Job Getcha, "Le grand canon pénitentiel de saint André de Crète: Une lecture typologique de l'histoire du salut" in: Carlo Braga, Alessandro Pistola (ed.), La liturgie, interprète de l'Écriture. II. Dans les compositions liturgiques, prières et chants. Conférences Saint-Serge. $49^{\circ}$ 
and Sebastian Pașcanu" ${ }^{146}$. The fundamental work of Andrew "illustrates and dramatizes a style of the self formed in a typological and dialectical relationship with the biblical narrative, particularly as that narrative might be ex-

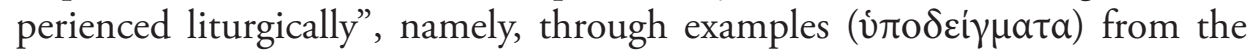
Testaments of the Holy Bible ${ }^{147}$.

As Mary B. Cunningham demonstrated, through its nature theme and through the use of typology and allegory, the kanon distances it self from the literal and narrative style of many kontakia and festal sermons ${ }^{148}$. Obviously, the topic is open to scientific discussion since under the influence of great hymnographers, as St. John of Damascus, the kanon indicates „intricate constructions in which typology, prophecy, metaphor, and many other methods of biblical exegesis come together" ${ }^{149}$. Compared to the use of typology in the kontakia, the kanon uses much less of this process ${ }^{150}$. Even at the philological level this is true, since following the philological analysis of the fundamental work of the Cretan author, we notice a rather small terminological "arsenal":

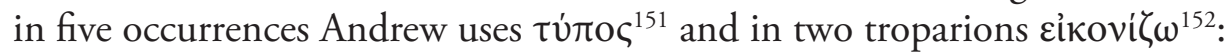

3.1. The image of Adam, alongside Eve, illustrates "Andrew's theology of human responsibility in the fall from Paradise and the expulsion from Eden" 153 . Adam is reflected in the Great Canon in three contexts ${ }^{154}$, none of them having a typological value. They are directly related to the reality that Adam is $\pi \rho \omega \tau$ ó $\pi \lambda \alpha \sigma \tau o \zeta$ and his expulsion from Paradise due to his disobedience towards the divine commandment. The third situation where the

Semaine d'Études Liturgiques, Rome 2003, p. 105-120; idem, "Reading the Bible with Andrew of Crete" in: Analele Ştiinţifice ale Universităţii "Alexandru Ioan Cuza" din Iaşi, SN, XII (2007), Iași 2007, p. 139-152.

146 Sebastian Paşcanu, Comentariu la Canonul cel Mare al Sfântului Andrei Criteanul, Bucharest ${ }^{2} 2006$.

${ }^{147}$ Derek Krueger, "The Great Kanon", p. 63.

${ }^{148}$ Mary B. Cunningham, "The reception of Romanos", p. 258.

149 Ibidem, p. 259-260.

150 See: Derek Krueger, “The Great Kanon”, p. 76.

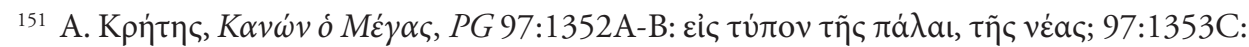

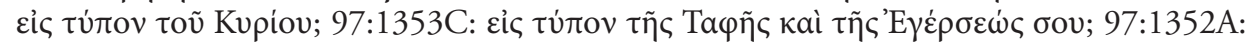

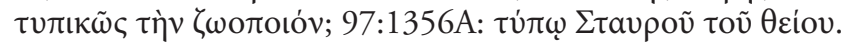

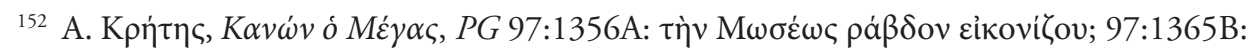

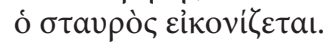

153 D. Krueger, “The Great Kanon”, p. 76.

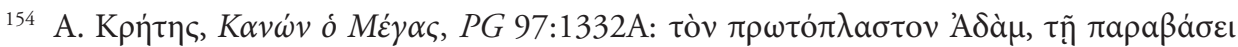

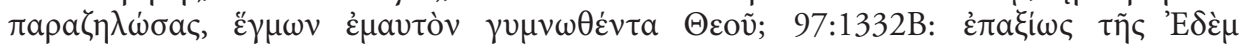

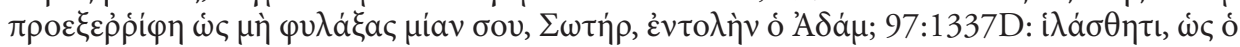

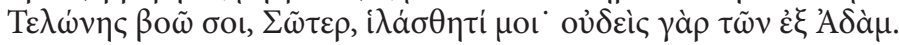


name "Adam" occurs has a rather spiritual reference: the author considers himself more sinful than anyone in Adam's breed. However, the theme of the image identifies the relationship between the old Adam and Christ, the "new Adam". If through Adam Paradise was lost and man met himself "stripped naked of God"155, through the New Adam, the One who wore "our image"156 and was crucified "in the midst of the earth" 157 the entire creation is restored.

3.2. Eve is presented in the Great Canon in two successive troparions. The image of "the first Eve" 158 or of "the physical Eve" 159 is linked, as in the case of Adam, to the moment of the fall in sin, by tasting from the tree, and

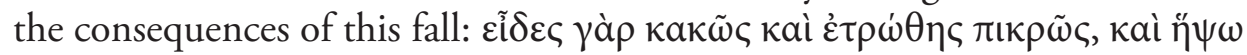

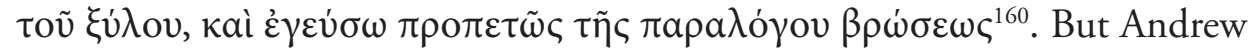
prefers to plasticize the face of Eve, comparing the fiery thought, which is located within man and through which the man is continuously led into $\sin ^{161}$, with the first woman in the world:

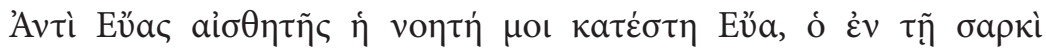

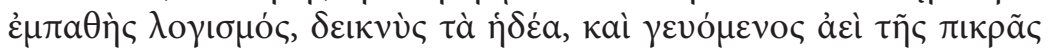
кататó $\varepsilon \varepsilon \omega \varsigma^{162}$.

Once again, in the case of Eve, the typological references are completely lacking in the Great Canon.

3.3. Closely related to the aspects regarding to protoparents is the theme of Paradise, of the leather clothes and the reality of the tree of life (or consciousness). The Paradise lost by Adam ${ }^{163}$ receives through Christ's sacrifice on the cross a new dimension: it becomes non-exclusive, it (re)opens to everyone ${ }^{164}$ and the first to enter to taste the "heavenly food" from Heaven is, paradoxically, a thief ${ }^{165}$.

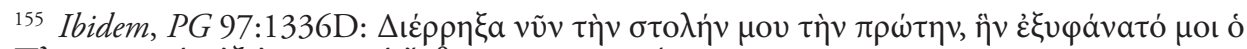

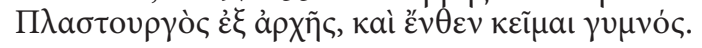

156 Ibidem, $P G$ 97:1361A: $\mu \varepsilon \mu о \rho \varphi \omega \mu \varepsilon \dot{v o v} \kappa a \theta ’ \dot{\eta} \mu \tilde{a} \varsigma$.

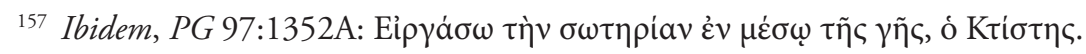

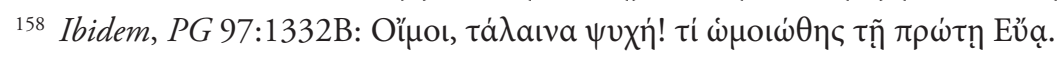

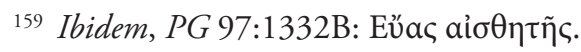

160 Ibidem, PG 97:1332B.

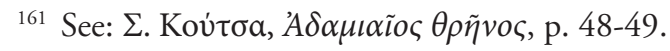

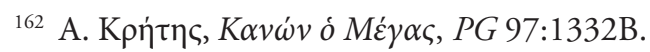

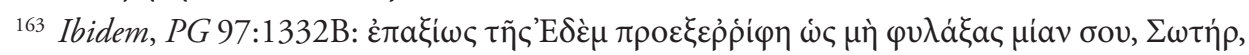

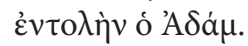

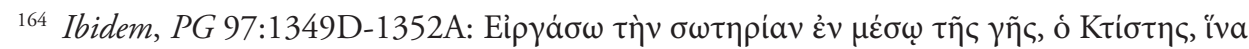

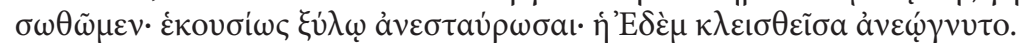

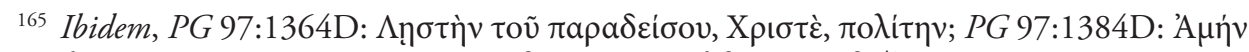

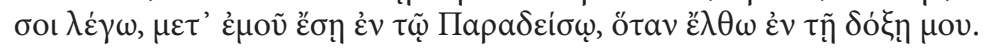


Clearly, the other two themes are directly related to the theme of Paradise: the touching of the tree and the gaze at its beauty led man to wear "robes of skin" (Gn 3:21) ${ }^{166}$, "torn robe"167 "raiment of shame"168 or of "coat of disgrace that is shamefully bloodstained" 169 , and in the end to the loss of Paradise. Andrew of Crete says, very explicitly, in his Canon that man "looked upon the beauty of the forbidden tree" 170 , fell badly and was bitterly hurt by touching the tree ${ }^{171}$, while to the original sin has "stitched for me robes of skin", emptying it from "the garment that God has woven for me" 172 . Once again, the typological references for the three themes are completely lacking.

3.4. Although it occurs in one troparion of the Great Canon, the face of

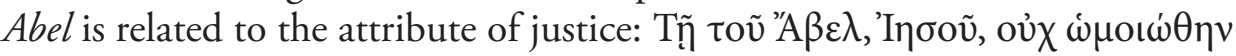
$\delta$ ¿кaı $v^{\prime} \eta^{173}$. It is also known throughout the entire patristic tradition that Abel symbolizes justice. He is the model "of the right man" 174 and the pre-imagining of the justice and the innocence of Christ. Obviously, the philology of the troparion itself in which appears the name of Abel clearly stresses the reference to the justice and innocent sacrifice of Abel as a prefiguration of Christ's sacrifice, since in the center of the chiasmus is found the expression

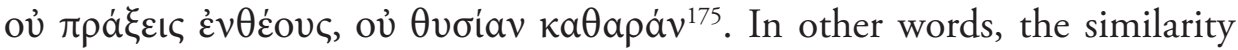
between the two characters stands in the sacrifice and in death ${ }^{176}$ : on the one hand, Abel brings gifts (sacrifices) favoured by God (Gn 4: 4; Heb 11: 4), and on the other hand, Christ brings himself as gift, as a sacrifice for the sins of the people (Php 2).

3.5. The typology of Enoch is not expressed directly by Andrew in his Canon. Although the Hymnographer recalls that the soul does not imitate

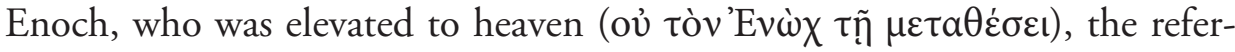

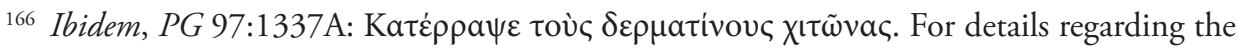

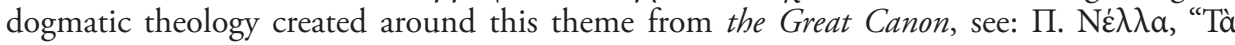

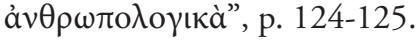

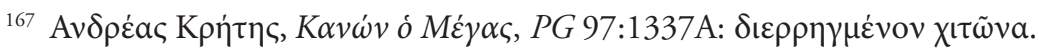

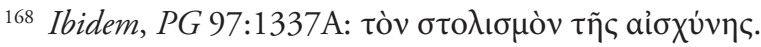

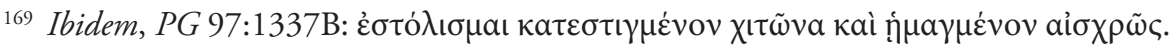

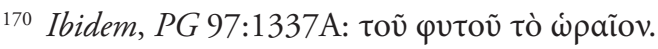

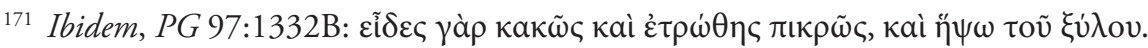

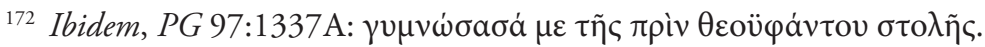

173 Ibidem, $P G$ 97:1332C.

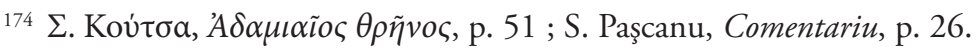

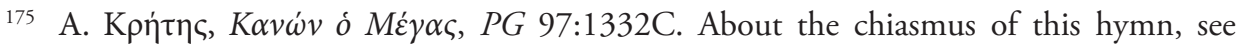
extensively in our research: "Canonul cel Mare al Sfântului Andrei Criteanul - aspecte tehnice (I)” in: Biserica şi lumea. Revistă de spiritualitate ortodoxă, II (2007), 1, p. 71.

176 S. Paşcanu, Comentariu, p. 26. 
ence to Christ's Ascension to Heaven is lacking. Moreover, we find a moral reference of the Byzantine Hymnographer. Through the face of Enoch, the Hymnographer seeks a possible comparison of the soul who, in the continuous road of spiritual ascendancy must break away from the earthly. However, one element nears him to Romanos's kontakia. Both Romanos the Melodist and Andrew of Crete link Enoch to the category of "righteous":

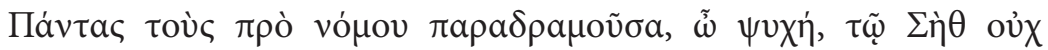

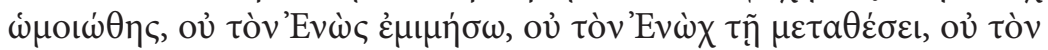

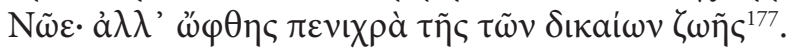

Such a moral reference is understood also by the insertion of the name of Enos, son of Seth ( $G n$ 4:26), which, according to the Fathers, signifies the union of the soul with the virtue ${ }^{178}$. In other words, the soul is called to a join the practicing of virtues to a new state, that of grace that penetrates and enlightens the soul to the knowledge of God. For the same moral reference there are also characters like Seth, Elijah ${ }^{179}$ and the Shunammite woman ${ }^{180}$.

3.6. Noah is related, as in the kontakia of Romanos, with the building of the ark. But Andrew prefers to unite, in his fundamental work, the saving of the world from the flood ${ }^{181}$ and implicitly of Noah's family, the one from the righteous family ${ }^{182}$, the salvation of mankind through Christ's Church, "the Ark of salvation" ( $\tau \tilde{\eta} \varsigma \sigma \omega \sigma \tau \iota \kappa \tilde{\eta} \varsigma \kappa \iota \beta \omega \tau o \tilde{v})$. In other words, Andrew of Crete sees in Noah's ark the typological image of the universal Church, which rescuses Man, since Christ is its Head:

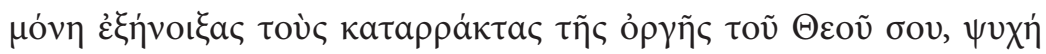

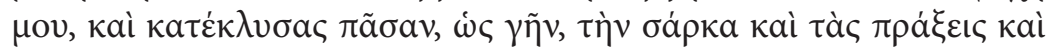

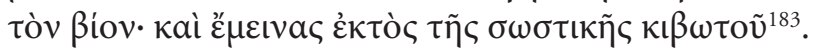

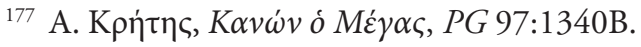

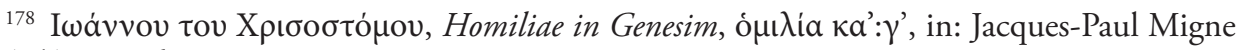
(ed.), Patrologia Graeca, 53, p. 179.

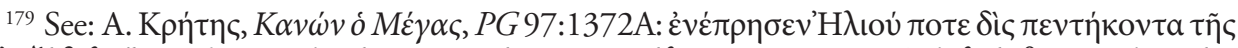

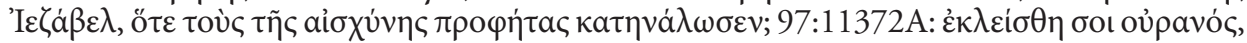

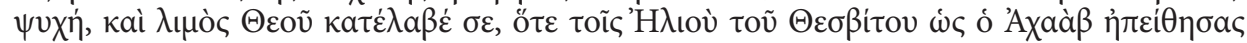

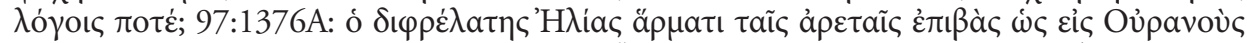

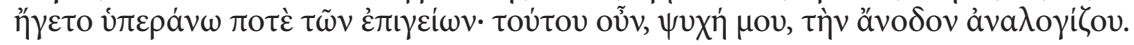

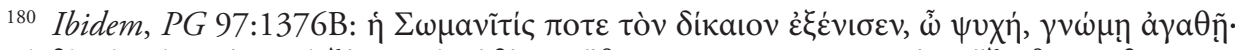

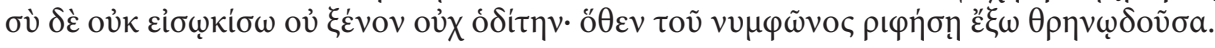

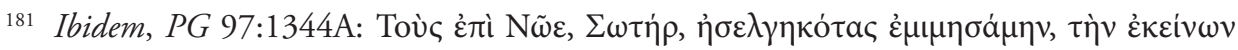

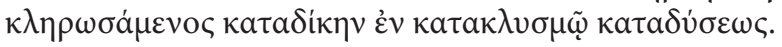

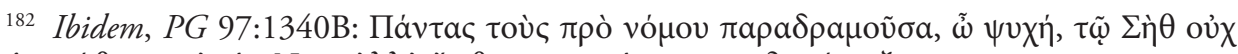

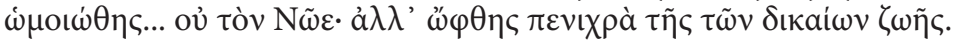

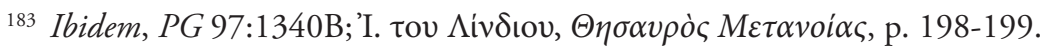


3.7. An enigmatic character in the the Old Testament, which prefigures Christ, is Melchizedek, king of Salem and priest of God (Gen 14:18). Andrew of Crete underlines his typological relationship to Christ in one troparion: tòv

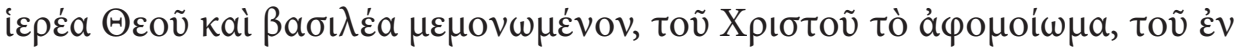

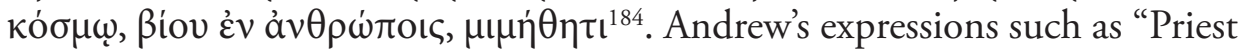
of God" ( $\tau$ òv i $\varepsilon \rho \varepsilon \dot{\varepsilon} \alpha \Theta \varepsilon o \tilde{)}$ ) and "king" ( $\beta a \sigma \iota \lambda \dot{\varepsilon} \alpha)$ suggest both the nearness to the biblical image of Melchizedek, as well as the erminia of his prototype ${ }^{185}$. Melchizedek, king, and at the same time, priest of God, passes the history of salvation as a figure of the Word of God ${ }^{186}$. We don't know his parents, being estranged in the world ( have a father as a Human, and, as God, did not have a mother, the One who was eternal, immortal, without beginning and without end - king and priest at the same time"187. Melchizedek is not a simple person through which God has worked in history but the prefigurative character of Christ, the Bishop, King and Master of the world.

3.8. Isaac is another typological exponent of Christ, found in the Great Canon $^{188}$. Obviously, his image is related to that of his father, Abraham, therefore, "in days of old left the land of his fathers and became a wanderer"

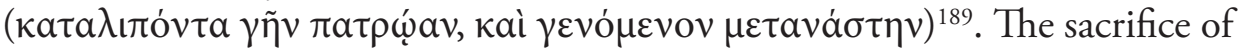
Isaac mentioned in a single troparion in the $\operatorname{Canon}^{190}$ prefigures "the image of Golgotha" ${ }^{191}$ where Christ broke "the deed of sin".

In full obedience to God, Abraham the man (symbol of God the Father, even though the Byzantine Hymnographer introduces him to us in the Canon only from a historical and spiritual perspective ${ }^{192}$ ) sacrifices his own

${ }^{184} P G 97: 1344 \mathrm{C}$.

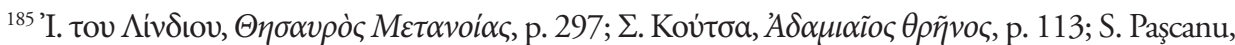
Comentariu, p. 52; J. Getcha, "Le grand canon", p. 117; idem, "Reading the Bible", p. 142.

186 O. Clément, Le chant des larmes, p. 59; idem, "Notes", p. 227.

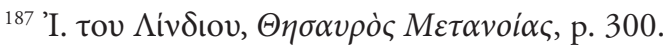

188 A. Giannouli, Die beiden byzantinischen Kommentare, p. 289: ${ }^{13-16} \mathrm{Kaì} \mathrm{oü \tau \omega} \mathrm{\tau ú \pi o \varsigma}$

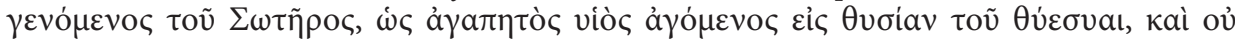

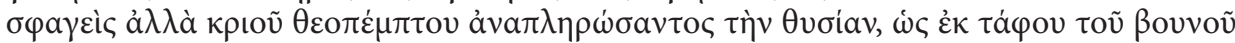

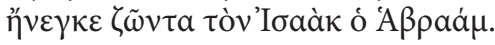

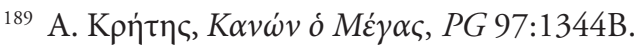

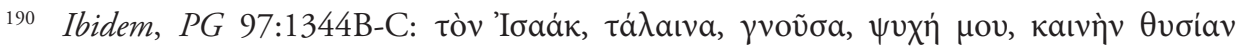

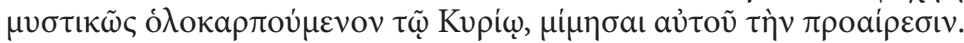

191 O. Clément, Le chant des larmes, p. 59.

192 Abraham's image is described in three consecutive troparions, which refer to two moments of his life: the leaving of the land of Haran (the first two hymns) and the philoxenia that

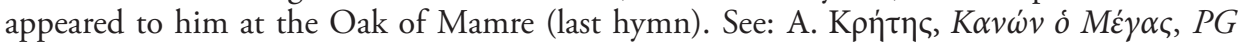
97:1344B. 
son, just as the Son of God, in full obedience to God, sacrificed himself and was sacrificed for the entire humankind ${ }^{193}$. The image of Isaac's sacrifice in the Old Testament reveals not only the typological form of Christ's sacrifice, but also the mysterious presence of Christ in the Old Covenant. Certainly Andrew sees in the death and sacrifice of Isaac the idea of the Resurrection of Christ.

3.9. Joseph the righteous is expressed in the Great Canon ${ }^{194}$ as the typological image of the entire life of Christ ${ }^{195}$. The typological relation of this character with Christ is expressed (also) at a philological level, through the insertion of $\tau$ útov. If in the case of the numerous Old Testament characters, the Byzantine Hymnographer presents the typology in a "disguised" manner, leaving the reader to read "between the lines" and about Joseph he says directly

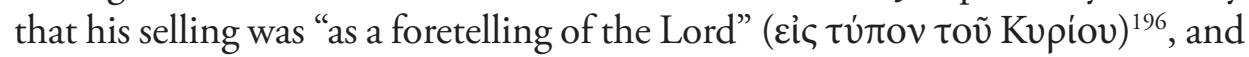
the indwelling in the pit is "was to prefigure Thy Burial and Resurrection" of

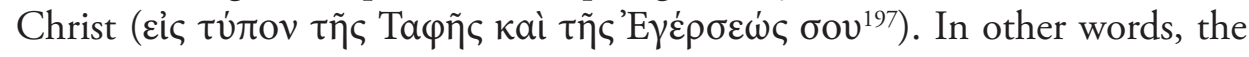
selling of Joseph by his brothers or "by his kinsmen" (ínò $\tau \tilde{\omega} v \sigma v \gamma \gamma$ óv $\omega v$ ) for twenty pieces of silver (Gn 37:1-36) prefigured the selling of the Saviour by Judas, while the indwelling in the pit without water prefigures the burial and Resurrection of the Lord ${ }^{198}$. The Byzantine Hymnographer seems atypical through the direct insertion of the two the typological forms. But his theological goal is not only to present a simple Old Testament character, in the present case of the history of Joseph, but to express to the audience the importance of Joseph within the history of salvation. Joseph is named by Andrew in two occurrences "the righteous" (

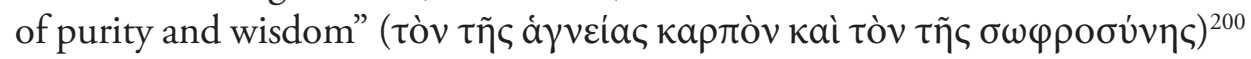

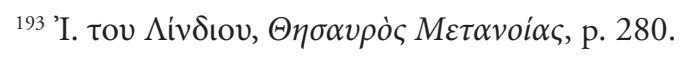

194 Joseph's image appears only in four consecutive occurrences from the Great Canon, two

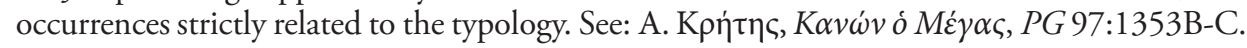

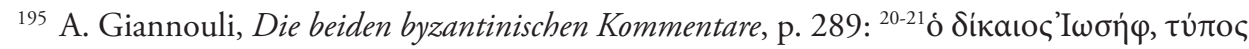

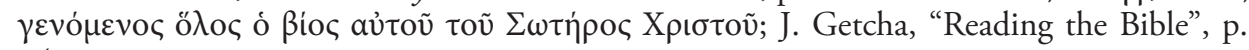
142.

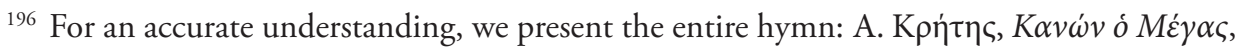

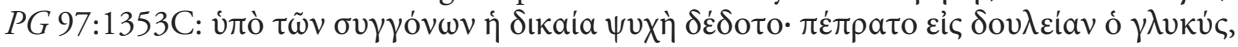

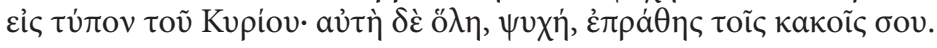

197 Ibidem, PG 97:1353C.

198 J. Getcha, “Le grand canon”, p. 117: “le séjour de Joseph dans la fosse est interprété

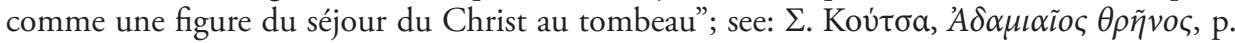
148, 150; O. Clément, Le chant des larmes, p. 59.

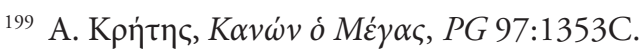

200 Ibidem, PG 97:1353B. 
or "the sweet" (ó $\gamma \lambda v \kappa v ́ \varsigma){ }^{201}$. This last expression is also given to Christ in an

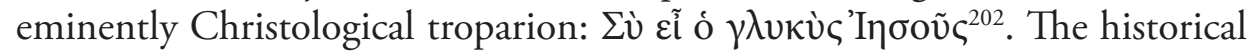
extension in the "case" of Joseph is clear: as the ancient was detested and sold at the price of a slave, so Christ was envied by those of His breed and sold by one of His fellows for a derisory amount of money.

3.10. Moses is another exponent of Andrew's typology. The eight occurrences where his name appears do not relate entirely to the typology. They are rather a concise examination of the life of Moses: from the rescue and accession from the house of Pharaoh to the passing with the people of Israel through the wilderness ${ }^{203}$. "Great Moses", the title awarded by the Byzantine Hymnographer in his fundamental work, is placed in typological relationship in the case of two instances, namely the marking and the hitting of the Red Sea through the middle of which passed the entire people of Israel and the hitting of the rock with his staff:

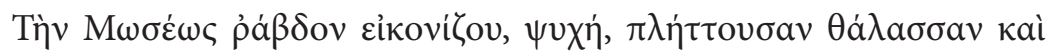

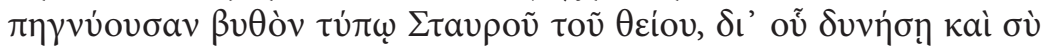
$\mu \varepsilon \gamma \alpha \dot{\lambda} \lambda \alpha \dot{\varepsilon} \kappa \tau \varepsilon \lambda \dot{\varepsilon} \sigma \alpha{ }^{204}$.

In other words, the rod of Moses speaks of Christ, who through the Cross leads his people to supreme freedom. Moses through the sign of the Cross covered the Egyptians and the Pharaoh's chariots ${ }^{205}$, using the Red Sea, while Christ through His sacrifice on the cross, destroyed death through His death. This theological expression of the Byzantine Hymnographer is emphasized both in the patristic tradition ${ }^{206}$ and in the hymnographic one $e^{207}$.

\footnotetext{
${ }^{201}$ Ibidem, PG 97:1353C.
}

202 Ibidem, $P G$ 97:1341D.

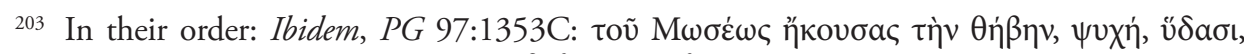

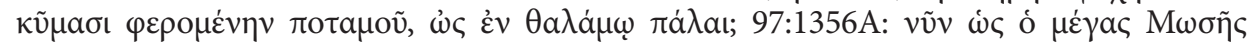

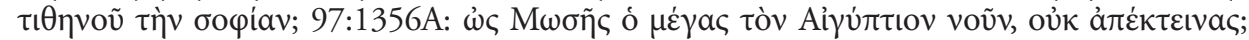

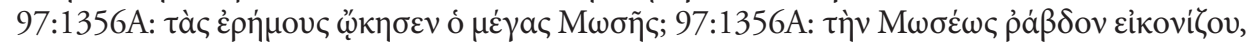

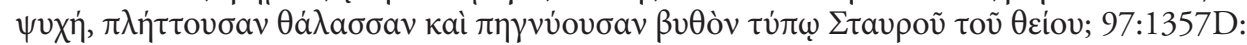

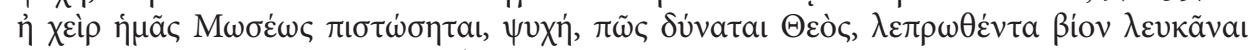

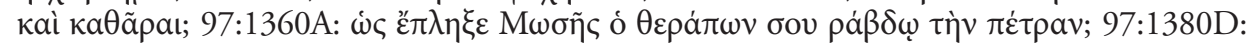

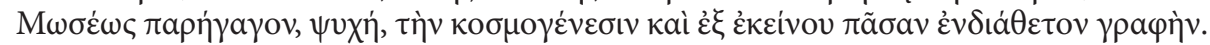

${ }^{204}$ Ibidem, PG 97:1356A.

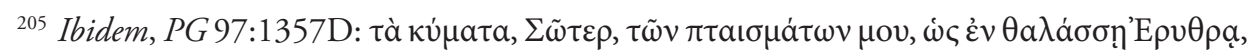

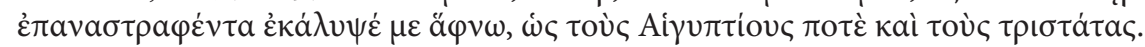

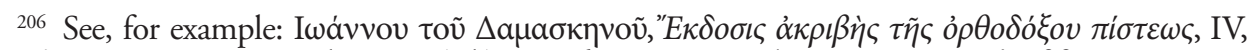

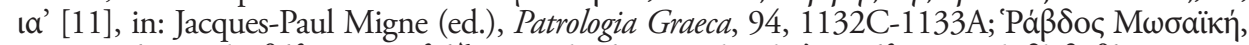

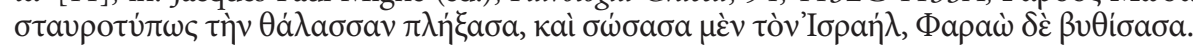

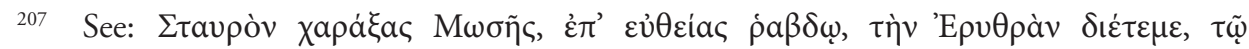

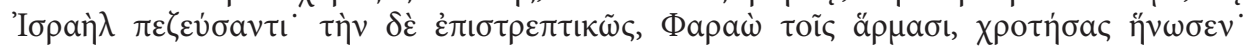


The second context is focused on the hitting of the rock with his the

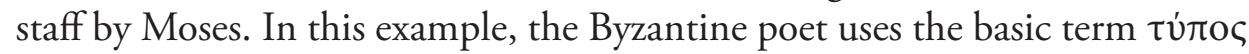
saying about the event from the wilderness that

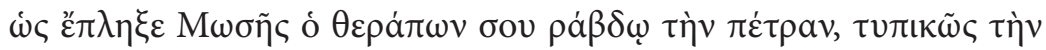

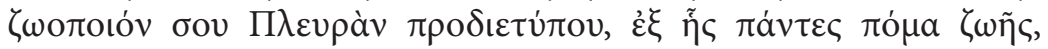
$\Sigma \omega \tau \eta \dot{\rho} \rho, \dot{\alpha} v \tau \lambda o \tilde{u} \mu \varepsilon v^{208}$.

Basically, the rod of Moses in the entire patristic literature is the type that prefigures the Holy Cross ${ }^{209}$. Although Moses is the one who achieves the

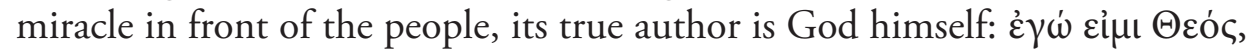

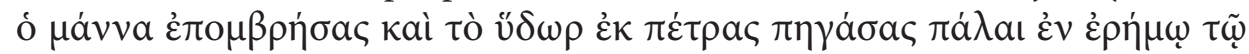
$\lambda \alpha \tilde{\omega} \mu \mathrm{ov}^{210}$.

\section{Instead of conclusions: several suggestions}

The typologies used by Romanos in his kontakia should not be understood as mere poetic techniques that offer a dramatic effect to his poems. Rather, they clearly "serve" in a theological sense that helps the Byzantine hymnologist in making his points: each of the Old Testament events helps to project their image towards the "fulfilment" in the Person of Christ, who reiterates the entire creation. Clearly, the use of typologies proves an extremely thorough knowledge of the biblical text. It is further proof that to the Fathers of the Church, the Scripture remains the main source. Each of its lines, every event, and every character is exhaustively explored by Romanos. He does not make theological poetry, but poetic theology. For Roman, theology, along with poetry and music, vibrates with Christological tones, so any typology he uses embeds itself on the incarnated divine Logos, who redeemed man through His sacrifice. Obviously, Romanos uses an entire "arsenal" of theological terminology to achieve his goal, without falling into the "temptation" of words. In other words, the Melodist did not lose the "appetite" for the Word, by becoming fascinated by the "appetite" for the words! Neither does

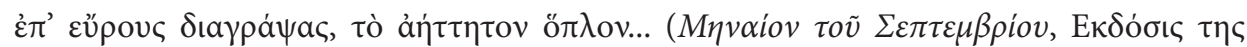

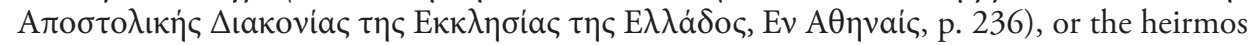

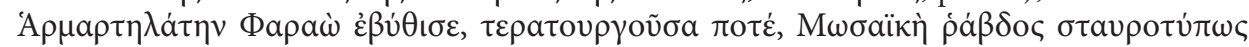

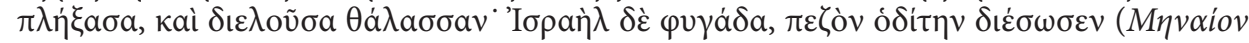

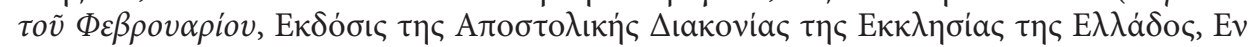
AӨpvais, p. 278-279).

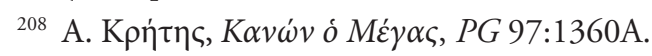

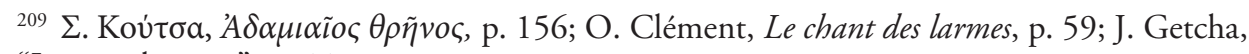
"Le grand canon", p. 117.

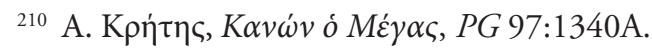


he "wrap up" his theological words for the sake of art, but out of love for the Word, which is revealed through and in words.

But does Andrew of Crete, Archbishop of Gortyna and inventor of the canon have the same theological vision when using typologies? Is he inspired by Romanos's typology? In order to provide an answer, we need to point out some of the peculiarities of the typologies used by Andrew of Crete in the Great Canon. First, in his fundamental work, we notice a rather small termi-

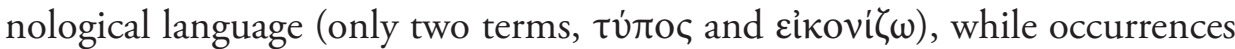
directly indicating this typological relationship are more reduced in comparison with Romanos's hymnography. Andrew is rather concerned with the spiritual nuances of the biblical text, looking for patterns that a soul must emulate on its way to the salvation in Christ.

Apart from this aspect, a first similarity between the two Hymnographers is related with the typology of Joseph and Moses. Only for these two Old Testament characters, both Andrew of Crete and Romanos the Melodist directly indicate the typological relationship. We do not know the cause of this identification and the mere expression of the acknowledgment of Romanos's influence on the fundamental work of Andrew - starting from this identification - is rather risky. We believe, however, that the use of these kontakia of Romanos's during the Great Lent, coupled with the reality that the text of the Great Canon was read from the very beginning in this "time of repentance" 211 , may indicate an alleged influence from the typology of Romanos.

Clearly, this idea finds support also at textual level. In other words, Andrew of Crete uses the specific terminology and Romanos's typology in the same contexts over the same characters (Joseph and Moses):

\section{Old Testament characters}

Joseph

\section{in Romanos the Melodist kontakia}

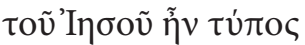

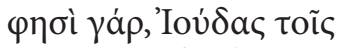

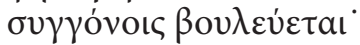

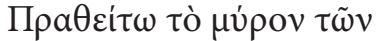
ả $\delta \varepsilon \lambda \varphi \tilde{\omega} v . \ddot{\omega}$ ảंò $\pi$ ó $\sigma \omega v$ $\gamma \varepsilon v \varepsilon \tilde{\omega} v \lambda \dot{\alpha} \mu \pi \varepsilon \iota^{\prime} I o v ́ \delta a \varsigma ! ~ \ddot{\omega} \tau \tilde{\eta} \varsigma$

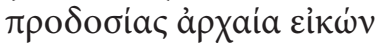

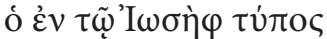

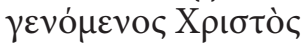

\section{in the Great Canon of Andrew of Crete}

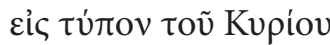

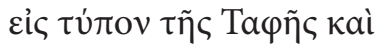
$\tau \tilde{\eta} \varsigma^{\prime} \mathrm{E} \gamma \varepsilon \dot{\varepsilon} \rho \varepsilon \dot{\omega} \varsigma$ бov

211 Perhaps even Andrew's troparion emphasizes its projection to be read during the Great

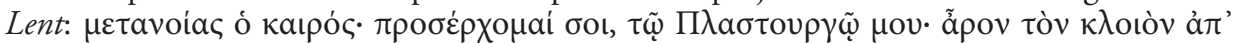

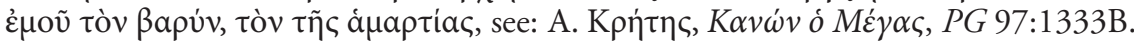




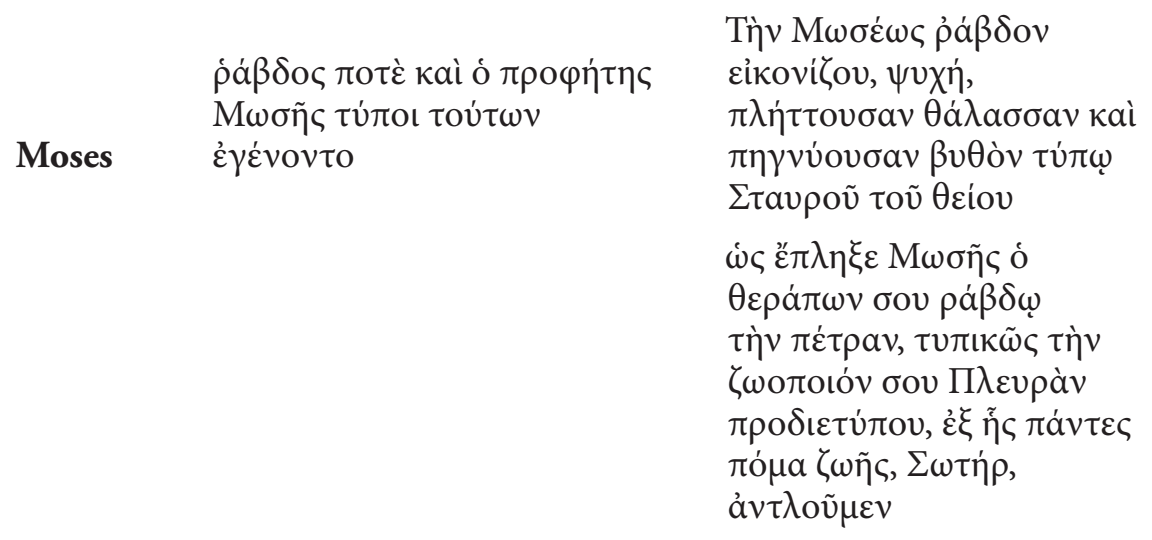

A distinction between the typological characters presented by Romanos and Andrew is given by the face of Melchizedek. Romanos seems to forget him in his kontakia, while Andrew - although in a terse form - remembers

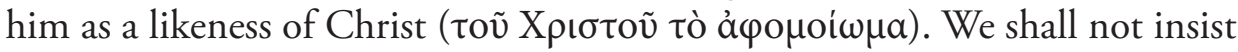
here on the theological content of this expression, but we believe that this reference confirms even more Andrew's attempt to provide typological models that Scripture itself indicates. The fact that for Melchizedek the expression

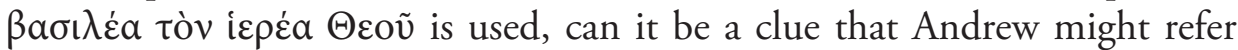
here, in a subtle manner, to the Byzantine emperor from his time? Hard to

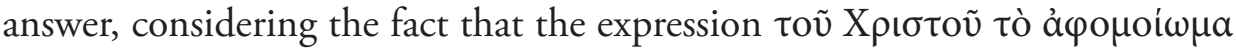
may be attributed only to an emperor who was orthodox in belief, namely either to Justinian II (685-695, 705-711) or to Anastasius II (713-715) or Theodosius III (715-718). To whom should it be attributed? Even harder to answer.

After all, the identification, classification and the erminia of the typologies clearly show us that in the research of the Christian hymnography not the quantitative nor the qualitative has the utmost importance, as neither the interrogation "Who is the greatest among the Hymnographers?", but the theological aim it develops and proposes to the contemporaries for a living confession. Only in this theological manner, the text and its author, the hymnography and the Hymnographer will lead us closer to Christ "the same yesterday, and today, and for ever" (Heb 13:8). 